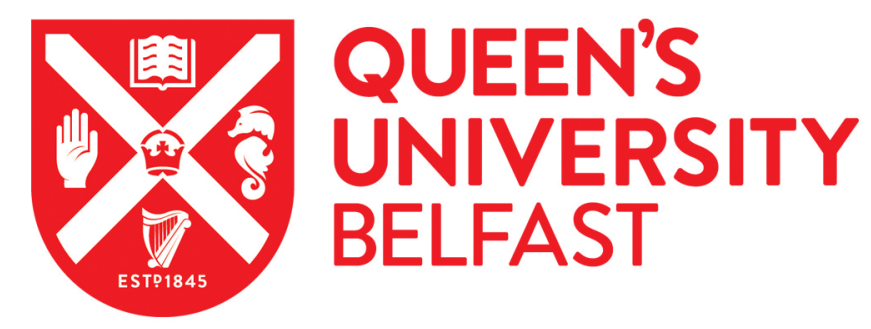

\title{
Micro-mechanical analysis of the in situ effect in polymer composite laminates
}

Arteiro, A., Catalanotti, G., Melro, A. R., Linde, P., \& Camanho, P. P. (2014). Micro-mechanical analysis of the in situ effect in polymer composite laminates. Composite Structures, 116, 827-840.

https://doi.org/10.1016/j.compstruct.2014.06.014

\section{Published in:}

Composite Structures

Document Version:

Peer reviewed version

Queen's University Belfast - Research Portal:

Link to publication record in Queen's University Belfast Research Portal

\section{Publisher rights}

(C) 2014 Elsevier Ltd. This manuscript version is made available under the CC-BY-NC-ND 4.0 license http://creativecommons.org/licenses/bync-nd/4.0/,which permits distribution and reproduction for non-commercial purposes, provided the author and source are cited.

\section{General rights}

Copyright for the publications made accessible via the Queen's University Belfast Research Portal is retained by the author(s) and / or other copyright owners and it is a condition of accessing these publications that users recognise and abide by the legal requirements associated with these rights.

Take down policy

The Research Portal is Queen's institutional repository that provides access to Queen's research output. Every effort has been made to ensure that content in the Research Portal does not infringe any person's rights, or applicable UK laws. If you discover content in the Research Portal that you believe breaches copyright or violates any law, please contact openaccess@qub.ac.uk. 


\section{Accepted Manuscript}

Micro-mechanical analysis of the in situ effect in polymer composite laminates

A. Arteiro, G. Catalanotti, A.R. Melro, P. Linde, P.P. Camanho

PII:

S0263-8223(14)00283-9

DOI: http://dx.doi.org/10.1016/j.compstruct.2014.06.014

Reference: COST 5747

To appear in:

Composite Structures

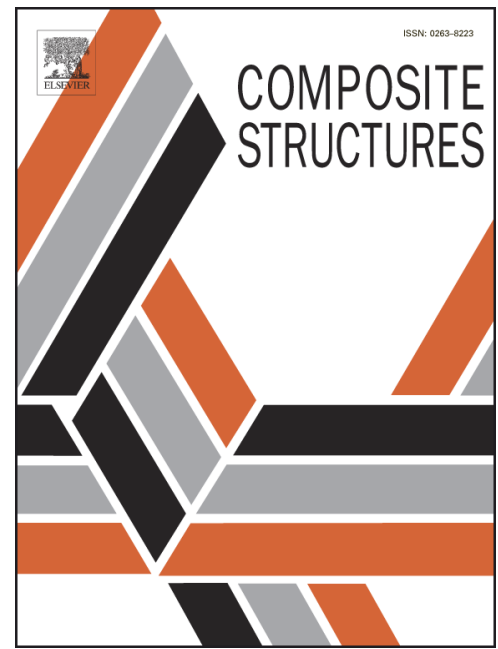

Please cite this article as: Arteiro, A., Catalanotti, G., Melro, A.R., Linde, P., Camanho, P.P., Micro-mechanical analysis of the in situ effect in polymer composite laminates, Composite Structures (2014), doi: http://dx.doi.org/ 10.1016/j.compstruct.2014.06.014

This is a PDF file of an unedited manuscript that has been accepted for publication. As a service to our customers we are providing this early version of the manuscript. The manuscript will undergo copyediting, typesetting, and review of the resulting proof before it is published in its final form. Please note that during the production process errors may be discovered which could affect the content, and all legal disclaimers that apply to the journal pertain. 


\title{
Micro-mechanical analysis of the in situ effect in polymer composite laminates
}

\author{
A. Arteiro ${ }^{a}$, G. Catalanotti ${ }^{\mathrm{a}}$, A.R. Melro ${ }^{\mathrm{b}}$, P. Linde $^{\mathrm{c}}$, P.P. Camanho ${ }^{\mathrm{a}, *}$ \\ ${ }^{a}$ DEMec, Faculdade de Engenharia, Universidade do Porto, Rua Dr. Roberto Frias, s/n, \\ 4200-465 Porto, Portugal \\ ${ }^{b}$ INEGI, Universidade do Porto, Rua Dr. Roberto Frias, 400, 4200-465 Porto, Portugal \\ ${ }^{c}$ AIRBUS Operations GmbH, Kreetslag 10, 21129 Hamburg, Germany
}

\begin{abstract}
A micro-mechanical finite element model of a composite sublaminate is proposed to study the mechanical response of ultra-thin plies, consisting of a representative volume element of a $90^{\circ}$ thin lamina in-between two homogenised $\pm \theta^{\circ}$ plies. Random fibre distributions, materially and statistically equivalent to real distributions, are analysed. A three-dimensional computational micromechanics framework, with a special focus on the elastic-plastic and damage constitutive behaviours of the matrix and on the response of the fibre-matrix interface, is used in the present analysis. Varying the $90^{\circ}$ ply thickness, it is possible to assess its effect on the mechanical response of laminated composites - the in situ effect. The proposed framework is able to accurately represent the micro-mechanical response of ultra-low grades, including (i) the mechanics of transverse cracking onset and propagation, (ii) the constraining effect observed in the laminae embedded in multidirectional laminates, (iii) the gradual, slow stress relaxation and progressive transverse cracking observed in very thin plies, and consequent increase of the crack density, (iv) the reduction in crack-opening displacement of the transverse cracks with ply thinness, (v) the formation of thin necks of matrix material around the regions where interfacial damage is more pronounced, and (vi) the in situ strengths.
\end{abstract}

\footnotetext{
*Corresponding author. Tel.: +351 225081753; fax: +351 225081445 .

Email address: pcamanho@fe.up.pt (P.P. Camanho)
} 
Keywords: laminates, in situ effect, micro-mechanics, FEA

\section{Introduction}

The effect of ply thickness on the onset of ply damage (transverse cracking) and delamination is extremely important for the prediction of the mechanical response of laminated composite structures. This is of particular significance when dealing with the most recent spread-tow, ultra-thin grades, where dry ply thicknesses can be extremely low.

The spread tow thin-ply technology $[1,2]$ is a recent technology of great interest. This technique is able to continuously and stably open fibre tows, and produce flat and straight plies with dry ply thicknesses as low as $0.02 \mathrm{~mm}$, considerably below the standard for CFRP low grade tapes. Widely opened tows can be cost-effectively obtained from thick tows, such as $12 \mathrm{~K}$ filament tows or higher, without damaging the filament fibres.

The potential benefits of such ultra-thin plies are several. On one hand, the use of thinner plies allows the production of thinner and lighter laminates and structures. On the other hand, per given laminate thickness, more plies can be accommodated (particularly interesting for thin laminates), increasing the design space and leading to a possibility of using smaller relative fibre angles between adjacent plies. This is beneficial when it comes to interfacial fracture between plies [3]. Also, by reducing the ply thickness in a multidirectional laminate, the in situ effect, characterised by an increase in transverse strength of a lamina constrained between two plies with a different fibre orientation, gains additional importance. Matrix cracking and delamination can, therefore, be delayed [4-6] without the use of special resins and/or through-the-thickness reinforcements, providing high strength and enhancing fatigue life. In terms of design and manufacturing, spread-tow plies are known to exhibit improved fibre orientation and distribution, potentially leading to fewer weak zones. Other benefits include easier homogenisation (opening perspectives for automated, continuous lay-up) and potential to use heavier tow yarns, which can significantly 
reduce production costs. There is also a huge potential for production of improved textile and non-crimp fabric reinforcements, whose handling and lay-up procedures, even over complex shapes, are much easier [7]; thinner fibre tows can result in lower crimp angles and in a reduced impact of the stitching yarns. Therefore, it is not surprising to see that the interest of the scientific and industrial communities in this new technology has increased drastically in the last years $[4-6,8-27]$.

When embedded in a multidirectional laminate, the laminae whose fibre orientation is perpendicular to the loading direction develops transverse cracks at strains lower than the failure strain of the entire laminate $[4,5]$. Consequently, the actual strengths and the crack density in such transverse plies typically are not only higher than those measured in unidirectional (UD) coupons, due to the constraints imposed by the neighbouring plies, as they reportedly increase with decreasing ply thickness $[4,5,28]$. In fact, early research about the strength prediction of multidirectional laminates has shown that using as ply properties those measured directly from UD plies, regardless of ply orientation or laminate thickness, results in very conservative predictions that could differ substantially from the experimental results [29].

Several experimental studies in the literature show that the transverse tensile strength $\left(Y_{T}\right)$ and the in-plane shear strength $\left(S_{L}\right)$ of a ply are function of ply thickness [29-35] and fibre orientation (or stiffness) of the adjacent plies [29, 33], whereas analysis methods show they are also a function of the ply's position in the laminate [28]; thus, they cannot be treated as intrinsic lamina properties $[29,33]$.

This is a deterministic size effect that occurs at the meso-scale, known as the in situ effect. Typically, it is taken into account by using fracture mechanics models that predict the relation between the ply thickness, its fracture toughness and the in situ strengths $[28,36]$, whose accurate determination is necessary for implementation of any physical based failure criteria for matrix cracking in constrained plies (see, for instance, Refs. [37-43]). Note that, in the case of in-plane shear, linear elastic fracture mechanics (LEFM) alone is not able 
to accurately predict the in situ strength, and the nonlinear shear response typically observed in laminated composites must be included in the prediction models [28].

For very low ply thicknesses, such as those of the thinner spread tows, fracture mechanics predictions of the in situ strengths yield asymptotic results when the ply thickness tends to zero. Therefore, an understanding of the in situ effect for such ply thinness is of crucial importance, namely for the development of physically meaningful analytical models applicable at this scale. However, experimental analysis based on in situ observations of very thin plies are extremely difficult, not only because it is hard to identify any transverse damage at this scale, but also because the applied strains needed to develop such damage mechanisms are so high that conduct to failure (or severe damage) of the constraining material. A possible way through for the understanding of the in situ effect is the use of computational micro-mechanics.

Recently, Saito et al. [4] experimentally evaluated transverse cracking constraining on thin-ply carbon-epoxy cross-ply laminates. The thickness of the inner $90^{\circ}$ layer varied between $0.040 \mathrm{~mm}$ (single ultra-thin ply) and $0.160 \mathrm{~mm}$ (block of four ultra-thin plies). In an interesting analysis approach, these authors reported a much lower crack-opening displacement (COD) for the thin $90^{\circ}$ ply when compared to blocks of two and four plies. This was clearly a constraining effect caused the stiff $0^{\circ}$ plies adjacent to the inner $90^{\circ}$ ply. For the thickest transverse laminae, the matrix crack extension, which occurred suddenly through the lamina thickness, led to stress relaxation, whereas, for the thinner transverse laminae, matrix cracking extended gradually, eventually without completely penetrating through the thickness, making stress relaxation much more difficult. The higher stress field maintained in the thinner transverse laminae caused, therefore, new matrix cracks to occur, increasing the crack density. A crack suppression effect was shown to exist, attributed to a decrease in the energy release rate (ERR) at the crack tip as the ply thickness decreases.

In a complementary study, Saito et al. [5] numerically investigated matrix cracking restriction in the inner transverse ply in a thin-ply laminate, and the 
effect of the stiffness of the adjacent plies, to clarify the mechanisms of transverse damage suppression in thin-ply laminates. A two-dimensional micro-mechanical model, simulating a representative volume element (RVE) of an embedded ply subjected to transverse tensile loading, where fibres and matrix were discretely represented, was used. A "weak interfacial strength" was assumed between matrix and fibres, modelled using cohesive elements in the interfaces. The fibres distribution in the RVE of the $90^{\circ}$ ply was modelled mimicking the in situ observations on the actual specimens tested in Ref. [4]. The widths of the RVEs were defined using the experimentally observed crack density information, such that the area modelled along the length direction contained only one transverse crack. An initial thermal step has been performed to account for the residual stresses of the curing process in the RVE. Standard boundary conditions were applied to the RVE. A bilinear elastic-plastic constitutive model was used to model the mechanical behaviour of the matrix. Failure was assumed to occur when the tensile or shear strains in the matrix reached their critical values, and the moduli of failed matrix was reduced to $10 \%$ of the original moduli. The numerical results were consistent with the experiments [4], with drastic penetration of the transverse cracks for the thicker $90^{\circ}$ plies. When having $45^{\circ}$ plies adjacent to the inner $90^{\circ}$ layer, matrix crack propagation was faster than when having $0^{\circ}$ adjacent plies, confirming the effect of the stiffness of adjacent plies on the constraining imposed to the $90^{\circ}$ laminae [33].

In order to improve the analysis carried out in Ref. [5], particularly through the analysis of transverse cracking development in ultra-thin plies with thicknesses as low as $0.020 \mathrm{~mm}$, a recent three-dimensional (3D) computational micro-mechanics framework $[44,45]$ is employed in the present work. This framework gives particular emphasis to the constitutive behaviour of the different constituents and to the characteristics of the RVEs under analysis, enabling an accurate representation of the micro-mechanical phenomena without relying on empirical observations.

The ability of damage models to predict physical phenomena, such as the initiation and propagation of damage, strongly depends on the scale (or resolution) 
at which the (failure) mechanisms under consideration are modelled [46, 47]. In fact, the conceptual idealisation of the damage process, i.e., the identification, characterisation and formulation of the governing physical principles of damage evolution, may span from molecular dynamics scales to structural mechanics scales, including the intermediate micro- and meso-mechanics [47]. In the case of composite laminates, where the in-plane dimensions exceed the length scale at which delamination, matrix cracking and fibre debonding take place by one to several orders of magnitude, the proper definition of the modelling scale has particular importance [46].

At lower structural scales, damage idealisations have higher resolution and higher kinematic freedom, and they are able to recreate all kinds of damage mechanisms, each of these captured with separate damage laws [47-49]. Micromechanical scale models, based on the constituent level, represent what is normally the smallest scale of composite damage idealisation [47, 49, 50]. Due to the sophistication of the modelling techniques and to the ever-increasing computational power, computational micro-mechanics has been emerging as an accurate and reliable tool to study the mechanical response of laminated composites. Within this framework, experimental data on the properties of the fibres and matrix materials, which are seen as individual homogeneous materials, are used to study the constitutive behaviour and to obtain the macroscopic properties of a composite lamina [49-51], not only the elastic constants, but also the strength properties under diverse loading conditions. Detailed matrix damage mechanisms, such as matrix plasticity and damage, and fibre-matrix interface cracking can be easily represented by means of the numerical simulation of the deformation and failure of an RVE of the microstructure, where fibre, matrix and their interface are modelled with the appropriate constitutive equations. Therefore, the micro-scale is the ideal damage scale to analyse intralaminar fracture, in particular the ply thickness and constraining (in situ) effects on matrix damage initiation and propagation.

An RVE can be defined as the smallest volume fraction of the material whose properties are representative of the global mechanical performance of the ma- 
terial system $[52,53]$. Therefore, an important issue when using computational micro-mechanics is the minimum size of the RVE. It cannot be too large, as this would endanger the possibility to numerically analyse it, but it cannot be too small, since it should contain all the necessary information about the statistical description of the microstructure, so that the average properties of this volume element are independent of its size and position within the material $[54,55]$. This critical RVE size depends on the phase and interface properties, and on the spatial distribution [54]. In addition to the size of the RVE, other important issues are fibre size distribution, volume fraction and spatial arrangement of reinforcements in the matrix. This spatial arrangement is usually not periodic and is highly dependent upon the manufacturing process [55]. To accurately reproduce the onset and evolution of damage in the matrix, it is important to represent properly the transverse randomness of the fibre distribution (i.e. distance to first neighbours, occurrence of clusters of fibres, etc.) $[55,56]$.

However, in the computational analysis of composite materials, periodic RVE are often employed, assuming that the material has a deterministic and ordered distribution of fibres, mainly because this assumption leads to lower computational costs $[56,57]$. To understand if this type of assumption conducts to worse results than when using RVEs with randomly distributed fibres, Trias et al. [57] compared the stress and strain distributions between a periodic and a random model for a carbon fibre reinforced polymer (CFRP), established in Ref. [56]. This comparison showed that periodic models can be used for the simulation of effective properties when the accuracy required is not so high (the difference in the Young's modulus was about $12 \%$ and in the Poisson's ratio about $6 \%$ ); however, for any statistical analysis or for the simulation of local phenomena such as local damage or matrix cracking, random models must be considered. Clearly, this is an important feature to take into account in the micro-mechanical analysis of the in situ effect.

Another relevant aspect in the development of micro-mechanical models is the correct definition of the constitutive behaviour of the composite material's constituents, in particular of the matrix material. For example, epoxy resins, 
which are typically used in advanced composite laminates, are known to be pressure dependent and extremely ductile under shear loading. Unlike the standard nonlinear models, such as the Mohr-Coulomb and the Drucker-Prager elasticplastic models, or other alternative plastic models that do not consider hardening effects, Melro et al. [44, 45] proposed and implemented a new pressure dependent, elastic-plastic thermodynamically consistent damage model that is able to properly represent the most relevant characteristics of epoxy matrices, namely the pressure dependency on its yield and failure behaviour, and the shear nonlinear-almost perfectly plastic behaviour.

In this work, a micro-mechanical finite element (FE) model of a thin-ply carbon-epoxy sublaminate, consisting of an RVE of a $90^{\circ}$ thin lamina in-between two homogenised $\pm \theta^{\circ}$ plies, is used to study the mechanical response of ultrathin spread tows. This RVE is created using an adaptation of the algorithm proposed in Ref. [55], which is able to generate random fibre distributions (even for high values of fibre volume fractions) that are materially and statistically equivalent to real distributions in the transverse cross-section of laminated composites. A computational micro-mechanics framework proposed recently $[44,45]$, with a special focus on the matrix material behaviour and fibre-matrix interface, is used in this analysis. The matrix is modelled using a pressure dependent, elastic-plastic damage model, and cohesive elements are used to model the interface between matrix and fibres [44]. Cohesive elements are also used to simulate delamination between the $90^{\circ}$ lamina and the adjacent homogenised $\pm \theta^{\circ}$ plies. Varying the $90^{\circ}$ ply thickness, it is possible to assess its effect on the mechanical response of laminated composites ( $i n$ situ effect). In addition, a truthful insight on the mechanics of thin-ply laminates is sought using the proposed micro-mechanical model, including a better understanding of their damage mechanics and of the mechanisms that preclude both microcracking and delamination, as observed elsewhere $[4,6,10,11,19,20,24,26]$. 


\section{Constitutive modelling}

The FE model of the thin-ply sublaminate consists of three main parts, namely a micro-mechanical RVE of a $90^{\circ}$ thin lamina, two adjacent homogenised $\pm \theta^{\circ}$ plies, and the interfaces between the $90^{\circ}$ lamina and the homogenised plies. The RVE of the $90^{\circ}$ thin lamina is composed by a random distribution of fibres, generated using an adaptation of the algorithm proposed in Ref. [55], embedded on an epoxy matrix, and the interfaces between fibres and matrix. The homogenised $\pm \theta^{\circ}$ plies are intended to simulate the mesoscopic elastic behaviour of the surrounding laminae and its effect on the mechanical response and on the damage initiation and growth in the mid- $90^{\circ}$ ply. The interfaces between the $90^{\circ}$ lamina and the homogenised plies, and the corresponding interlaminar damage onset and propagation, are simulated using cohesive elements. The constitutive models for each of these materials are briefly described in the following sections.

\subsection{Reinforcing fibres}

In this work, a simple transversely isotropic, linear-elastic constitutive model is used to simulate the individual reinforcing carbon fibres. The diameter of the individual fibres is considered constant in the entire RVE [45]. Table 1 shows the material properties of standard carbon fibres, used in the present micromechanical model.

[Table 1 about here.]

\subsection{Epoxy matrix}

The epoxy matrix is modelled using the elastic-plastic constitutive model with damage proposed in Ref. [44], implemented as an UMAT user subroutine of the FE commercial software Abaqus ${ }^{\circledR}$ [58]. The initial elastic behaviour is defined by a linear relation between the stress tensor and the elastic strain. A paraboloidal yield criterion, defined as a function of the stress tensor and 
of the compressive and tensile yield strengths, is used together with a nonassociative flow rule, which allows for a correct definition of the volumetric deformation in plasticity. The tensile and compressive hardening functions are provided by two piecewise functions of the equivalent plastic strain. Since it is fully differentiable, the paraboloidal yield function is integrated by means of a general return mapping algorithm.

Damage in the epoxy matrix is modelled by a single damage variable that affects only the Young's modulus of the material once activated. This isotropic damage model is defined in a thermodynamically consistent way, ensuring irreversibility of the damage process. Damage onset is defined by a damage activation function similar to the paraboloidal yield criterion, but using the final compressive and tensile strengths of the epoxy matrix instead of yield strengths and the concept of effective stress tensor, i.e., the stress tensor calculated using the undamaged stiffness tensor [44]. To avoid damage localisation (mesh size dependency), Bazănt and Oh's crack band model [59], which makes use of the characteristic length of the FE and the fracture toughness of the epoxy matrix to regularise the computed dissipated energy, is implemented along with the definition of the damage evolution law [44]. The chosen damage evolution law forces damage localisation and strain softening on the material under tensile load, but under compressive load, the influence of the hydrostatic pressure causes a different evolution of the damage variable. The progression of damage is softer than in the tensile case, which suggests a slower propagation of damage [44]. For more details, the reader is referred to Refs. [44, 45].

Fiedler et al. [60] characterized the stress-strain behaviour of a typical epoxy matrix material (Toho \# 113) under tension, compression and shear. The relevant elastic and strength properties needed to model the material behaviour of the epoxy matrix were extracted from these experimental results, as well as the hardening data for both tension and compression. The plastic Poisson's ratio has been determined by Guild et al. [61], which is considered a standard value for epoxy resins, and the fracture toughness (or critical energy release rate, $\mathcal{G}_{c}$ ) used in this work is a mean value of the values reported in the literature [45]. 
The epoxy matrix material properties are shown in table 2, and the yield curves for both tension and compression are shown in figure 1.

[Table 2 about here.]

[Figure 1 about here.]

\subsection{Fibre-matrix interface}

The interface between fibre and matrix is modelled using the cohesive elements of the FE commercial software Abaqus ${ }^{\circledR}$ [58]. The cohesive element behaviour is defined by a bilinear traction-separation damage law. Mode dependent cohesive elements' strengths are considered, and the rate of damage progression is controlled by the fracture energy (or critical energy release rate) of the cohesive element under mode I, mode II, or mixed-mode, according to the BK law [62].

Table 3 shows the material properties of the fibre-matrix interface. The initial stiffness $K$ is set to maintain continuity of the stress and strain fields between fibres and matrix. The values of the interface fracture energies $\mathcal{G}_{I c}$ and $\mathcal{G}_{I I c}$, although somewhat low, are justified not only by experimental evidence (see, for instance, Varna et al. [63]), but also from previous micro-mechanical numerical analyses [45, 64], which have demonstrated that the brittle behaviour in transverse tension typical of composites is only captured for such low values of interfacial toughness [45].

[Table 3 about here.]

\subsection{Homogenised outer plies}

The outer plies are modelled assuming a linear-elastic transversely isotropic material behaviour. Since they are introduced in the micro-mechanical model to assess the effect of the stiffness of the adjacent plies in the mechanical response and damage evolution of the intermediate $90^{\circ}$ lamina, no nonlinear or fracture behaviour are considered. 
The IM7/8552 carbon-epoxy composite laminate is used to model the outer plies of the proposed RVE, as the corresponding material properties are available in several publications [65-67]. Table 4 shows the relevant material properties.

[Table 4 about here.]

\subsection{Plies interface}

The interfaces between the intermediate $90^{\circ}$ lamina and the adjacent homogenised $\pm \theta^{\circ}$ plies are modelled using the cohesive elements in Abaqus ${ }^{\circledR}$ [58]. Similarly to the fibre-matrix interface, the cohesive element behaviour is defined by a mode dependent bilinear traction-separation damage law. Once again, the rate of damage progression is controlled by the fracture energy of the cohesive element under mode I, mode II, or mixed-mode, according to the BK law [62].

The interlaminar properties of the IM7/8552 carbon-epoxy composite laminate [39] are used to model the interfaces between the intermediate $90^{\circ}$ lamina and the adjacent homogenised $\pm \theta^{\circ}$ plies. The main reason for this consideration is the use of the IM7/8552 elastic and physical properties to model the homogenised outer plies. Table 5 shows the corresponding material properties.

[Table 5 about here.]

\section{Finite element modelling}

\subsection{Finite element discretisation}

Figure 2 shows a schematic view of the thin-ply sublaminate RVE, where $b$ is the thickness of the intermediate $90^{\circ}$ lamina ( $z z$-direction), $t$ is the thickness of each individual outer ply, constant and equal to $0.075 \mathrm{~mm}$ throughout the analysis, $a$ is the RVE's width (yy-direction), defined to ensure the representativeness of the different RVEs analysed in the present work (see table 6), $c$ is the RVE's thickness ( $x x$-direction), constant and approximately equal to two times the average element size of the $90^{\circ}$ ply mesh, and $\theta$ is the orientation of the outer plies, which is kept constant and equal to $0^{\circ}$. 
[Figure 2 about here.]

[Table 6 about here.]

Different 3D RVEs of the thin-ply sublaminate, with varying transverse ply thickness $(b)$ and, when necessary, varying RVE's width $(a)$ — see figure 2 and table 6 - have been generated using an adaptation of the algorithm proposed by Melro et al. [55]. Several $90^{\circ}$ ply thicknesses are studied, spanning from the ultra-thin $0.02 \mathrm{~mm}$ to the more conventional $0.14 \mathrm{~mm}$.

Following Melro et al. [45], linear hexahedral elements with reduced integration (Abaqus ${ }^{\circledR}$ C3D8R) are used to generate the mesh of the $90^{\circ}$ intermediate ply (both matrix and fibres). However, due to the randomness of the distribution of reinforcements and consequent difficulties to mesh this geometry, some linear wedge elements (Abaqus ${ }^{\circledR}$ C3D6) are also included in the mesh. According to Melro et al. [45], the wedge elements present no influence in the meso-mechanical behaviour of the composite. Abaqus ${ }^{\circledR}$ C3D8R elements are also used to generate the mesh of the homogenised outer plies. For the interface between fibres and matrix and for the interface between the mid- $90^{\circ}$ ply and adjacent homogenised plies, 8-node cohesive elements (Abaqus ${ }^{\circledR}$ COH3D8) are used. Figure 3 shows a representative FE discretisation of part of an RVE with a $0.040 \mathrm{~mm}$ thick $90^{\circ}$ intermediate ply.

[Figure 3 about here.]

\subsection{Loading and boundary conditions}

A transverse tensile load is applied to the RVE, corresponding to a total homogenised strain of $2.0 \%$ in the transverse $(y y$-) direction, resulting in transverse damage in the RVE.

Periodic boundary conditions (PBCs) are applied to the thin-ply sublaminate RVEs in the $x x$ - and $y y$-directions. Although the authors recognise that the use of this type of boundary conditions affects the damage pattern results [45], and that additional studies have to be conducted to assess its impact, it is 
considered that the appropriate definition of boundary conditions in RVE-based modelling is outside the scope of the present work.

The imposition of PBCs in the finite element analysis (FEA) follows Melro et al. [45]. Linear multi-point constraints are used, i.e., kinematic constraints imposed on the degrees of freedom of each pair of nodes belonging to opposite faces, edges or vertices of the RVE. These equations include the corresponding degrees of freedom, as well as the far-field applied strains. Depending on the nodes position - faces, edges or vertices - a different set of equations is applied to their degrees of freedom to solve compatibility issues between different kinematic constraints [45].

\section{Results and discussion}

Figures 4 to 7 show the contour plots of the matrix damage variable on RVEs of $90^{\circ}$ laminae with thicknesses between $0.020 \mathrm{~mm}$ and $0.080 \mathrm{~mm}$ at applied strains ranging from $0.6 \%$ to $2.0 \%$. Only sublaminates with $0^{\circ}$ outer plies are considered. Figure 8 shows the contour plots of the equivalent plastic strain in the matrix at an applied strain of $2.0 \%$. Although only one random distribution of fibres is presented for each case, it is representative of other random distributions in terms of damage localisation.

[Figure 4 about here.]

[Figure 5 about here.]

[Figure 6 about here.]

[Figure 7 about here.]

[Figure 8 about here.]

As expected, a crack develops along a direction transverse to the applied load (see figures 4 to 7 ). Similarly to what was observed experimentally from in situ observations [4] (and confirmed numerically in Ref. [5]), damage starts in 
the narrower portions of matrix between the closest adjacent fibres aligned with the loading direction at approximately the same applied strain (in the present case at around $0.56-0.58 \%$ ), first as fibre-matrix decohesions, then followed by matrix cracking. Even though not clear in figure 4a, due to the reduced COD, for an applied strain of $0.6 \%$ fibre-matrix decohesion has also occurred in the thinner $(0.020 \mathrm{~mm}$ thick $)$ transverse ply. This can be seen in more detail in figure 9, which shows the damage variable of the cohesive elements in the interface between fibre and matrix in a detail of the $0.020 \mathrm{~mm}$ thick ply RVE.

[Figure 9 about here.]

The in situ observations presented in Ref. [4] have also shown that, for the thicker $90^{\circ}$ plies, once a transverse crack is formed, it rapidly penetrates through the thickness. This was also observed in the present simulations, as shown in figures 10 to 12 for more conventional transverse ply thicknesses. Notice that, due to the enormous computational cost of these models, the sublaminate RVEs with transverse ply thicknesses above or equal to $0.100 \mathrm{~mm}$ have been modelled in order to accommodate a single transverse crack (as in Ref. [5], for example), with a reduction of the total width of the RVEs when compared to the thinply sublaminates. It is recognised that, particularly during softening, the size of the RVE may affect the material response. Nevertheless, even though the models for the thicker RVEs shown in figures 10 to 12 may not be completely representative in terms of damage progression after full extension of the first (single) transverse crack, they are useful in showing the differences in terms of damage evolution in a first stage of transverse crack propagation.

[Figure 10 about here.]

[Figure 11 about here.]

[Figure 12 about here.]

In the case of the thinner transverse plies, crack extension reportedly slows down with increasing applied strain [4]. In the numerical simulations presented 
in this work, the same trend is observed (compare, for example, figures 5 and 7 and the experimental observations reported in Ref. [4]). This becomes even more clear observing figure 13, showing the normalised crack length, obtained by dividing the length of the transverse crack by the $90^{\circ}$ ply thickness, as a function of applied strain. The length of the transverse crack is given by the base distance between the nodes in the tips of the longer transverse crack in the RVE. The numerical results for a representative random distribution of sublaminate RVEs with $0.020 \mathrm{~mm}, 0.080 \mathrm{~mm}$ and $0.140 \mathrm{~mm}$ thick transverse plies are shown.

[Figure 13 about here.]

As reported by Saito et al. [4], for the thickest transverse laminae, the sudden matrix crack extension leads to stress relaxation, whereas the thinner transverse laminae show a gradual extension of the transverse cracks, eventually without completely penetrating through the thickness (see figure 13). Therefore, stress relaxation is much more difficult in this case — see figures 14 and 15, showing the transverse stress field $\left(\sigma_{22}\right)$ in cracked $0.020 \mathrm{~mm}$ and $0.080 \mathrm{~mm}$ thick $90^{\circ}$ plies, obtained from the proposed micro-mechanical models. As discussed in Ref. [4], this higher stress field in the thinner transverse laminae results in an increase of the crack density of the thinner plies, as can be observed in figures 4 to 7 (this progressive fragmentation and multiple cracking of ultra-thin plies has been exploited, for example, by Czél and Wisnom [20] to produce pseudo-ductile high strength hybrid composite materials).

[Figure 14 about here.]

[Figure 15 about here.]

The ability of the proposed micro-mechanical models to predict the gradual, slow stress relaxation and progressive transverse cracking in thin and ultra-thin plies can also be observed looking at the homogenised stress-strain curves of the embedded $90^{\circ}$ ply shown in figure 16 for the different sublaminate RVEs. 
The results for only one representative sublaminate RVE per $90^{\circ}$ ply thickness have been plotted, to facilitate the analysis. Volumetric homogenisation was performed to obtain the homogenised stress-strain curves [45]:

$$
\sigma_{i j}^{0}=\frac{1}{V} \int_{V} \sigma_{i j} \mathrm{~d} V=\frac{1}{V} \sum_{k=1}^{N_{p}} \sigma_{i j}^{k} V^{k}
$$

where $\sigma_{i j}^{0}$ is the homogenised stress component, $\sigma_{i j}^{k}$ and $V^{k}$ are the stress component determined at integration point $k$ and associated volume, and $N_{p}$ is the total number of integration points in the RVE. Note that, after the onset of damage, which occurs approximately at the same applied strain (as observed elsewhere $[4,5])$, softening is more gradual for the thinner transverse plies, becoming steeper and with more pronounced jumps as the ply thickness increases. For more conventional ply thicknesses, this progressive softening behaviour is not observed, and the appearance of the first crack generally corresponds to firstply-failure (as stressed before, the sublaminate RVEs with the thicker transverse plies, due to the reduced size of the RVE justified by limitations in computational power, may not be completely representative in terms of damage progression after full extension of the first transverse crack, reason why the homogenised stress-strain curves have not been shown for these cases).

[Figure 16 about here.]

Another very interesting finding reported by Saito et al. [4] and also observed in the present simulations is related with the COD of the transverse cracks in $90^{\circ}$ plies of different thicknesses. Due to the constraining effect imposed by the adjacent $0^{\circ}$ plies, the COD in the thinner $90^{\circ}$ plies was much smaller than observed in the thicker (compare figures 4 to 7 and 10 to 12), as observed experimentally [4]. Figure 17 shows the COD as a function of the applied strain for sublaminate RVEs with $0.020 \mathrm{~mm}, 0.080 \mathrm{~mm}$ and $0.140 \mathrm{~mm}$ thick transverse plies. The COD is determined as the higher relative displacement between adjacent nodes in the surface of a transverse crack. Only one representative random distribution per sublaminate RVE is considered to facilitate the analysis. 
Similar trends to those reported in Ref. [4] can be observed.

[Figure 17 about here.]

Another interesting result of the numerical simulations, also confirmed by experimental evidence, is the formation of thin necks of matrix material around the regions where interfacial damage is more pronounced; such damage mechanism was also reported in the numerical analyses presented by Melro et al. [45]. The in situ observations presented by Saito et al. [4] suggest that this phenomenon is potentiated by increasing ply thicknesses, since it could barely be seen in the thinner $0.040 \mathrm{~mm}$ thick $90^{\circ}$ plies, an effect also captured in the present simulations, as shown in figure 8. For a comparison with more conventional ply thicknesses, see also figure 18 .

[Figure 18 about here.]

Figure 19 shows the in situ transverse strength as a function of the ply thickness calculated from the micro-mechanical models presented in this work. The applied remote strain corresponding to the extension of a transverse crack through the thickness of the $90^{\circ}$ ply is used together with the elastic properties determined from a linear-elastic analysis of the same RVE to calculate the in situ strength. Since a clear transverse crack did not penetrate completely through the thinner $(0.020 \mathrm{~mm}$ and $0.040 \mathrm{~mm}$ thick) plies, the in situ transverse strengths for these two cases could not be determined (it should be noted that, for an applied strain of $2.0 \%$, the longitudinal stress in the outer $0^{\circ}$ plies is above $4000 \mathrm{MPa}$ ). The trends typically observed experimentally [30-34] could be reproduced.

[Figure 19 about here.]

\section{Concluding remarks}

A recent 3D computational micro-mechanics framework [44, 45] has been employed in this work to study the micro-mechanics of the in situ effect in 
tow-spread, ultra-thin plies. In a comparison with a thorough experimental study on similar grades [4], it was observed that the proposed framework is able to accurately represent the micro-mechanical response of ultra-low grades, including (i) the mechanics of transverse cracking onset and propagation, (ii) the constraining effect observed in the laminae embedded in multidirectional laminates, (iii) the gradual, slow stress relaxation and progressive transverse cracking observed in very thin plies, and consequent increase of the crack density, (iv) the reduction in COD of the transverse cracks with ply thinness due to the constraining effect imposed by the adjacent stiffer laminae, (v) the formation of thin necks of matrix material around the regions where interfacial damage is more pronounced, a phenomenon potentiated by increasing ply thicknesses, and (vi) the in situ effect, characterised by a reduction in the applied stress needed to extend a transverse crack along the thickness of the ply when the ply thickness increases. This work is seen as an improvement over initial models [5] with respect to the understanding and representation of the physics of matrix cracking suppression in very thin plies.

Besides the transverse tensile and the in-plane shear strengths, experimental studies have also shown that a substantial reduction in longitudinal compression and transverse shear strengths can result from transverse cracking (see Ref. [33] for earlier references). Therefore, the in situ effect may also play an important role on the delay of other matrix-dominated failure mechanisms.

This has already been addressed through the application of 3D phenomenological failure criteria, viz. Ref. [42]. According to the formulation presented in Ref. [42], when embedded in a multidirectional laminate, not only the transverse tensile strength $\left(Y_{T}\right)$ and the in-plane shear strength $\left(S_{L}\right)$ must be regarded as in situ properties (calculated using the models deduced in Ref. [28]), but also the transverse compressive strength $\left(Y_{C}\right)$ and the transverse shear strength $\left(S_{T}\right)$. These are calculated as a function of the in situ in-plane shear strength, fracture angle under pure transverse compression and longitudinal friction co- 
efficient [42]. On the other hand, assuming that kink bands ${ }^{1}$ are triggered by localised matrix failure in the vicinity of misaligned fibres, the in situ effect must have a direct, positive influence on the resistance to fibre kinking [42], therefore affecting the longitudinal compressive behaviour of laminated composites, as observed experimentally, according to Ref. [33].

In the future, as a follow-up, the present methodology will also be applied to the cases of transverse compression, in-plane shear and transverse shear stress states. In addition, emphasis will be given not only to the effect of the transverse ply thickness, but also to the effect of the stiffness of the adjacent plies and ply position in the laminate (for instance, placing the $90^{\circ}$ ply at the surface of the laminate). These analyses are intended to support the understanding of the micro-mechanical constitutive behaviour of ultra-thin (embedded) plies under such basic stress states, overcoming the complexities and limitations of experimental testing on such low grade materials.

\section{Acknowledgements}

This work was funded by AIRBUS under project 2genComp — second generation Composites. The authors gratefully acknowledge the support provided by AIRBUS.

The first and second authors would also like to acknowledge the support of the Fundação para a Ciência e a Tecnologia under grants SFRH/BD/88593/2012 and FCT-DFRH-SFRH-BPD-78104-2011, respectively.

\section{References}

[1] Kawabe K, Matsuo T, Maekawa Z. New technology for opening various reinforcing fiber tows. J Soc Mat Sci Jpn 1998;47(7):727-734 (in Japanese).

\footnotetext{
${ }^{1}$ Crack-like type of failure occurring in UD laminates subjected to compressive loadings, in which the fibres undergo microbuckling $[68,69]$.
} 
[2] Kawabe K. New spreading technology for carbon fiber tow and its application to composite materials. Sen-i Gakkaishi 2008;64(8):262-267 (in Japanese).

[3] Tao J, Sun CT. Influence of ply orientation on delamination in composite laminates. J Compos Mater 1998;32(21):1933-1947.

[4] Saito H, Takeuchi H, Kimpara I. Experimental evaluation of the damage growth restraining in $90^{\circ}$ layer of thin-ply CFRP cross-ply laminates. Adv Compos Mater 2012;21:57-66.

[5] Saito H, Takeuchi H, Kimpara I. A study of crack suppression mechanism of thin-ply carbon-fiber-reinforced polymer laminate with mesoscopic numerical simulation. J Compos Mater 2013. DOI: 10.1177/0021998313494430.

[6] Amacher R, Cugnoni J, Botsis J. Thin ply composites: experimental characterization and modeling. In: Proceedings of the 19th International Conference on Composite Materials (ICCM-19), Montreal, 28 July - 2 August 2013. p. 1-13.

[7] Athreya SR, Ma L, Barpanda D, Jacob G, Verghese N. Estimation of inplane elastic properties of stitch-bonded, non-crimp fabric composites for engineering applications. J Compos Mater 2014;48(2):143-154.

[8] Sasayama H, Kawabe K, Tomoda S, Ohsawa I, Kageyama K, Ogata N. Effect of lamina thickness on first ply failure in multidirectionally laminated composites. J Jpn Soc Compos Mater 2004;30(4):142-148 (in Japanese).

[9] Nishikawa Y, Miki T, Okubo K, Fujii T, Kawabe K. Fatigue behaviour of plain-woven CF/epoxy composites using spread tows (effect of tow thickness on crack formation). Trans Jpn Soc Mech Eng A 2005;71(710):13561361 (in Japanese).

[10] Nishikawa Y, Okubo K, Fujii T, Kawabe K. Fatigue crack constraint in plain-woven CFRP using newly-developed spread tows. Int J Fatigue 2006;28:1248-1253. 
[11] Sihn S, Kim RY, Kawabe K, Tsai SW. Experimental studies of thin-ply laminated composites. Compos Sci Technol 2007;67:996-1008.

[12] Kawabe K, Sasayama H, Kageyama K, Ogata N. Effect of ply thickness on compressive properties in multidirectionally laminated composites. J Jpn Soc Compos Mater 2008;34:173-181 (in Japanese).

[13] Yokozeki T, Aoki Y, Ogasawara T. Experimental characterization of strength and damage resistance properties of thin-ply carbon fiber/toughened epoxy laminates. Compos Struct 2008;82:382-389.

[14] Yokozeki T, Kuroda A, Yoshimura A, Ogasawara T, Aoki T. Damage characterization in thin-ply composite laminates under out-of-plane transverse loading. Compos Struct 2010;93:49-57.

[15] Moon J, Kim M, Kim C, Bhowmik S. Improvement of tensile properties of CFRP composites under LEO space environment by applying MWNTs and thin-ply. Compos Part A-Appl S 2011;42:694-701.

[16] Saito H, Morita M, Kawabe K, Kanesaki M, Takeuchi H, Tanaka M, Kimpara I. Effect of ply-thickness on impact damage morphology in CFRP laminates. J Reinf Plast Comp 2011;30:1097-1106.

[17] Takagi K, Nakatani H, Suga K, Koike A, Ogihara S. Effect of ply thickness on mechanical property of CFRP symmetric angle-ply laminates. In: Proceedings of the 18th International Conference on Composite Materials (ICCM-18), Jeju Island, 21-26 August 2011. p. 1-4.

[18] El-Dessouky HM, Lawrence CA, McGrail T, Broughton WR. Ultralightweight carbon fibre/thermoplastic composite material using spread tow technology. Compos Part B-Eng 2013;50:91-97.

[19] Arteiro A, Catalanotti G, Xavier J, Camanho PP. Notched response of non-crimp fabric thin-ply laminates. Compos Sci Technol 2013;79:97-114. 
[20] Czél G, Wisnom MR. Demonstration of pseudo-ductility in high performance glass/epoxy composites by hybridisation with thin-ply carbon prepreg. Compos Part A-Appl S 2013;52:23-30.

[21] Arteiro A, Catalanotti G, Xavier J, Camanho PP. Notched response of noncrimp fabric thin-ply laminates: Analysis methods. Compos Sci Technol $2013 ; 88: 165-171$.

[22] Linde P, Heltsch N, Kruse T, Das S, Vernier C. Second generation composites. 19. Nationales Symposium — SAMPE Deutschland e.V., Hamburg, 27-28 February 2013. p. 1-2 (in German).

[23] Kuraishi A, Itoh T, Kimoto J, Ochi S, Hirano N. Applicability of C-ply Bi-angle ${ }^{\mathrm{TM}} \mathrm{NCF}$ to aircraft parts. In: Proceedings of the 19th International Conference on Composite Materials (ICCM-19), Montreal, 28 July - 2 August 2013. p. 1-11.

[24] Fuller J, Wisnom MR. Damage suppression in thin ply angle-ply carbon/epoxy laminates. In: Proceedings of the 19th International Conference on Composite Materials (ICCM-19), Montreal, 28 July - 2 August 2013. p. $1-9$.

[25] Arteiro A, Catalanotti G, Xavier J, Camanho PP. Large damage capability of non-crimp fabric thin-ply laminates. Compos Part A-Appl S $2014 ; 63: 110-122$.

[26] Guillamet G, Turon A, Costa J, Renart J, Linde P, Mayugo JA. Damage occurrence at edges of non-crimp-fabric thin-ply laminates under off-axis uniaxial loading. Compos Sci Technol 2014;98:44-50.

[27] Baley C, Lan M, Davies P, Cartié D. Porosity in ocean racing yacht composites: a review. Appl Compos Mater 2014:1-16. DOI: 10.1007/s10443014-9393-4. 
[28] Camanho PP, Dávila CG, Pinho ST, Iannucci L, Robinson P. Prediction of in situ strengths and matrix cracking in composites under transverse tension and in-plane shear. Compos Part A-Appl S 2006;37:165-176.

[29] Chang F-K, Chen M-H. The in situ ply shear strength distribution in graphite/epoxy laminated composites. J Compos Mater 1987;21:708-733.

[30] Garrett KW, Bailey JE. Multiple transverse fracture in $90^{\circ}$ cross-ply laminates of a glass fibre-reinforced polyester. J Mater Sci 1977;12:157-168.

[31] Parvizi A, Garrett KW, Bailey JE. Constrained cracking in glass fibrereinforced epoxy cross-ply laminates. J Mater Sci 1978;13:195-201.

[32] Parvizi A, Bailey JE. On multiple transverse cracking in glass fibre epoxy cross-ply laminates. J Mater Sci 1978;13:2131-2136.

[33] Flaggs DL, Kural MH. Experimental determination of the in situ transverse lamina strength in graphite/epoxy laminates. J Compos Mater $1982 ; 16: 103-116$.

[34] Boniface L, Smith PA, Bader MG. Transverse ply cracking in cross-ply CFRP laminates - Initiation or propagation controlled? J Compos Mater $1997 ; 31(11): 1080-1112$.

[35] Sebaey TA, Costa J, Maimí P, Batista Y, Blanco N, Mayugo JA. Measurement of the in situ transverse tensile strength of composite plies by means of the real time monitoring of microcracking. Compos Part B-Eng 2014 (in press). DOI: http://dx.doi.org/10.1016/j.compositesb.2014.02.001.

[36] Dvorak GJ, Laws N. Analysis of progressive matrix cracking in composite laminates II. First ply failure. J Compos Mater 1987; 21:309-329.

[37] Flaggs DL. Prediction of tensile matrix failure in composite laminates. J Compos Mater 1985;19:29-50.

[38] Dávila CG, Camanho PP, Rose CA. Failure criteria for FRP laminates. J Compos Mater 2005;39(4):323-345. 
[39] Camanho PP, Maimí P, Dávila CG. Prediction of size effects in notched laminates using continuum damage mechanics. Compos Sci Technol 2007;67:2715-2727.

[40] Maimí P, Camanho PP, Mayugo JA, Dávila CG. A continuum damage model for composite laminates: Part I - Constitutive model. Mech Mater 2007;39:897-908.

[41] Mayugo JA, Camanho PP, Maimí P, Dávila CG. Analytical modelling of transverse matrix cracking of $\left\{ \pm \theta / 90^{n}\right\}^{s}$ composite laminates under multiaxial loading. Mech Adv Mater Struc 2010;17:237-245.

[42] Catalanotti G, Camanho PP, Marques AT. Three-dimensional failure criteria for fiber-reinforced laminates. Compos Struct 2013;95:63-79.

[43] Camanho PP, Bessa MA, Catalanotti G, Vogler M, Rolfes R. Modeling the inelastic deformation and fracture of polymer composites - Part II: Smeared crack model. Mech Mater 2013;59:36-49.

[44] Melro AR, Camanho PP, Pires FMA, Pinho ST. Micromechanical analysis of polymer composites reinforced by unidirectional fibres: Part I - Constitutive modelling. Int J Solids Struct 2013;50:1897-1905.

[45] Melro AR, Camanho PP, Pires FMA, Pinho ST. Micromechanical analysis of polymer composites reinforced by unidirectional fibres: Part II Micromechanical analyses. Int J Solids Struct 2013;50:1906-1915.

[46] de Borst R, Remmers JJC. Computational Methods for Debonding in Composites. In: Camanho PP, Dávila CG, Pinho ST, Remmers JJC, editors. Mechanical Response of Composites, chapter 1. Oñate E, Series editor. Computational Methods in Applied Sciences, volume 10. Dordrecht: Springer, 2008. p. 1-25.

[47] Dávila CG, Rose CA, Iarve EV. Modeling fracture and complex crack networks in laminated composites. In: Mantič V, editor. Mathematical Methods and Models in Composites, chapter 8. Aliabadi FMH, Series editor. 
Computational and Experimental Methods in Structures, volume 5. London: Imperial College Press, 2014. p. 297-347.

[48] Ladevèze P, Lubineau G, Violeau D, Marsal D. A computational damage micromodel for laminate composites. In: Sadowski T, editor. IUTAM Symposium on Multscale Modelling of Damage and Fracture Processes in Composite Materials. Dordrecht: Springer, 2006. p. 1-12.

[49] Melro AR. Analytical and numerical modelling of damage and fracture of advanced composites. PhD thesis. University of Porto, Porto, 2011.

[50] Soden PD, Kaddour AS, Hinton MJ. Recommendations for designers and researchers resulting from the world-wide failure exercise. Compos Sci Technol 2004;64:589-604.

[51] Tsai SW. Theory of Composites Design. Stanford: Stanford University, 2008.

[52] Tessitore N, Riccio A. A novel FEM model for biaxial non-crimp fabric composite materials under tension. Comput Struct 2006;84:1200-1207.

[53] Petriccione A, Annicchiarico D, Antonucci V, Giordano M, Riccio A, Scaramuzzino F. A stiffness volume averaging based approach to model noncrimp fabric reinforced composites. Compos Sci Technol 2012;72:360-369.

[54] González C, Llorca J. Mechanical behavior of unidirectional fiber-reinforced polymers under transverse compression: Microscopic mechanisms and modeling. Compos Sci Technol 2007;67:2795-2806.

[55] Melro AR, Camanho PP, Pinho ST. Generation of random distribution of fibres in long-fibre reinforced composites. Compos Sci Technol 2008;68:20922102 .

[56] Trias D, Costa J, Turon A, Hurtado JE. Determination of the critical size of a statistical representative volume element (SRVE) for carbon reinforced polymers. Acta Mater 2006;54:3471-3484. 
[57] Trias D, Costa J, Mayugo JA, Hurtado JE. Random models versus periodic models for fiber reinforced composites. Comp Mater Sci 2006;38:316-324.

[58] ABAQUS 6.12 Documentation. Dassault Systèmes Simulia Corp., Providence, 2012.

[59] Bažant ZP, Oh BH. Crack band theory for fracture of concrete. Mater Struct 1983;16(93):155-177.

[60] Fiedler B, Hojo M, Ochiai S, Schulte K, Ando M. Failure behavior of an epoxy matrix under different kinds of static loading. Compos Sci Technol 2001;61:1615-1624.

[61] Guild FJ, Potter KD, Heinrich J, Adams RD, Wisnom MR. Understanding and control of adhesive crack propagation in bonded joints between carbon fibre composite adherents II. Finite element analysis. Int J Adhes Adhes 2001;21:445-453.

[62] Benzeggagh M, Kenane M. Measurement of mixed-mode delamination fracture toughness of unidirectional glass/epoxy composites with mixed-mode bending apparatus. Compos Sci Technol 1996;56:439-449.

[63] Varna J, Berglund LA, Ericson ML. Transverse single-fibre test for interfacial debonding in composites: 2. Modelling. Compos Part A-Appl S 1997;28A:317-326.

[64] Vaughan TJ, McCarthy CT. Micromechanical modelling of the transverse damage behaviour in fibre reinforced composites. Compos Sci Technol 2011;71:388-396.

[65] Camanho PP, Lambert M. A design methodology for mechanically fastened joints in laminated composite materials. Compos Sci Technol 2006;66:30043020 .

[66] Wisnom MR, Khan B, Hallett SR. Size effects in unnotched tensile strength of unidirectional and quasi-isotropic carbon/epoxy composites. Compos Struct $2008 ; 84: 21-28$. 
[67] Koerber H, Xavier J, Camanho PP. High strain rate characterisation of unidirectional carbon-epoxy IM7-8552 in transverse compression and inplane shear using digital image correlation. Mech Mater 2010;42:1004-1019.

[68] Budiansky B, Fleck NA, Amazigo JC. On kink-band propagation in fiber composites. J Mech Phys Solids 1998;46(9):1637-1653.

[69] Bažant ZP. Size effect. Int J Solids Struct 2000;37:69-80. 


\section{List of Figures}

1 Yield curves given in equivalent stress vs. equivalent plastic strain. 30

2 Schematic of the RVE of a thin-ply sublaminate. . . . . . . . . . 31

3 Representative FE model of part of an RVE with a $0.040 \mathrm{~mm}$ thick transverse ply. . . . . . . . . . . . . . 32

4 Contour plots of the matrix damage variable on an RVE of a $0.020 \mathrm{~mm}$ thick $90^{\circ}$ lamina of a sublaminate with $0^{\circ}$ outer plies (only the $90^{\circ}$ lamina is shown). . . . . . . . . . 33

5 Contour plots of the matrix damage variable on an RVE of a $0.040 \mathrm{~mm}$ thick $90^{\circ}$ lamina of a sublaminate with $0^{\circ}$ outer plies (only the $90^{\circ}$ lamina is shown). . . . . . . . . . . .

6 Contour plots of the matrix damage variable on an RVE of a $0.060 \mathrm{~mm}$ thick $90^{\circ}$ lamina of a sublaminate with $0^{\circ}$ outer plies (only the $90^{\circ}$ lamina is shown). . . . . . . . . . . .

7 Contour plots of the matrix damage variable on an RVE of a $0.080 \mathrm{~mm}$ thick $90^{\circ}$ lamina of a sublaminate with $0^{\circ}$ outer plies (only the $90^{\circ}$ lamina is shown).

8 Contour plots of the equivalent plastic strain in the matrix of RVEs of $90^{\circ}$ laminae on thin-ply sublaminates with $0^{\circ}$ outer plies, at an applied strain of $2.0 \%$ (only the $90^{\circ}$ laminae are shown).

9 Damage variable of the cohesive elements representing the interface between fibre and matrix in a detail of the $0.020 \mathrm{~mm}$ thick ply RVE at an applied strain of $0.6 \%$. . . . . . . . . . . . 38

10 Contour plots of the matrix damage variable on an RVE of a $0.100 \mathrm{~mm}$ thick $90^{\circ}$ lamina of a sublaminate with $0^{\circ}$ outer plies (only the $90^{\circ}$ lamina is shown). . . . . . . . . . . .

11 Contour plots of the matrix damage variable on an RVE of a $0.120 \mathrm{~mm}$ thick $90^{\circ}$ lamina of a sublaminate with $0^{\circ}$ outer plies (only the $90^{\circ}$ lamina is shown). . . . . . . . . . . .

12 Contour plots of the matrix damage variable on an RVE of a $0.140 \mathrm{~mm}$ thick $90^{\circ}$ lamina of a sublaminate with $0^{\circ}$ outer plies (only the $90^{\circ}$ lamina is shown). . . . . . . . . . . . .

13 Normalised crack length as a function of applied strain for sublaminate RVEs with $0.020 \mathrm{~mm}, 0.080 \mathrm{~mm}$ and $0.140 \mathrm{~mm}$ thick transverse plies. . . . . . . . . . . . . . . . . . . 42

14 Transverse stress field $\left(\sigma_{22}\right)$ in a cracked $0.020 \mathrm{~mm}$ thick $90^{\circ}$ ply of a sublaminate with $0^{\circ}$ outer plies (only the matrix material of the $90^{\circ}$ ply is shown). . . . . . . . . . . . . . . .

15 Transverse stress field $\left(\sigma_{22}\right)$ in a cracked $0.080 \mathrm{~mm}$ thick $90^{\circ}$ ply of a sublaminate with $0^{\circ}$ outer plies (only the matrix material of the $90^{\circ}$ ply is shown). . . . . . . . . . . . . . .

16 Homogenised stress-strain curves of the embedded $90^{\circ}$ ply for sublaminates with $0^{\circ}$ outer plies. (For interpretation of the references to colour in this figure legend, the reader is referred to the web version of this article.) . . . . . . . . . . . 
17 COD as a function of applied strain for sublaminate RVEs with $0.020 \mathrm{~mm}, 0.080 \mathrm{~mm}$ and $0.140 \mathrm{~mm}$ thick transverse plies. . . . . 46

18 Contour plots of the equivalent plastic strain in the matrix of RVEs of $90^{\circ}$ laminae on sublaminates with $0^{\circ}$ outer plies, at an applied strain of $2.0 \%$ (only the $90^{\circ}$ laminae are shown). . . . . . 47

19 In situ transverse strength as a function of the ply thickness. 


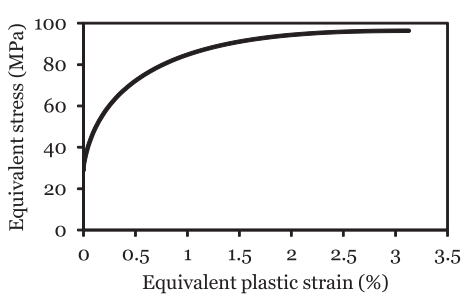

(a) Tensile hardening curve.

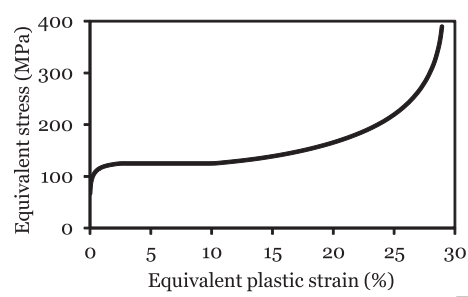

(b) Compressive hardening curve.

Figure 1: Yield curves given in equivalent stress vs. equivalent plastic strain. 


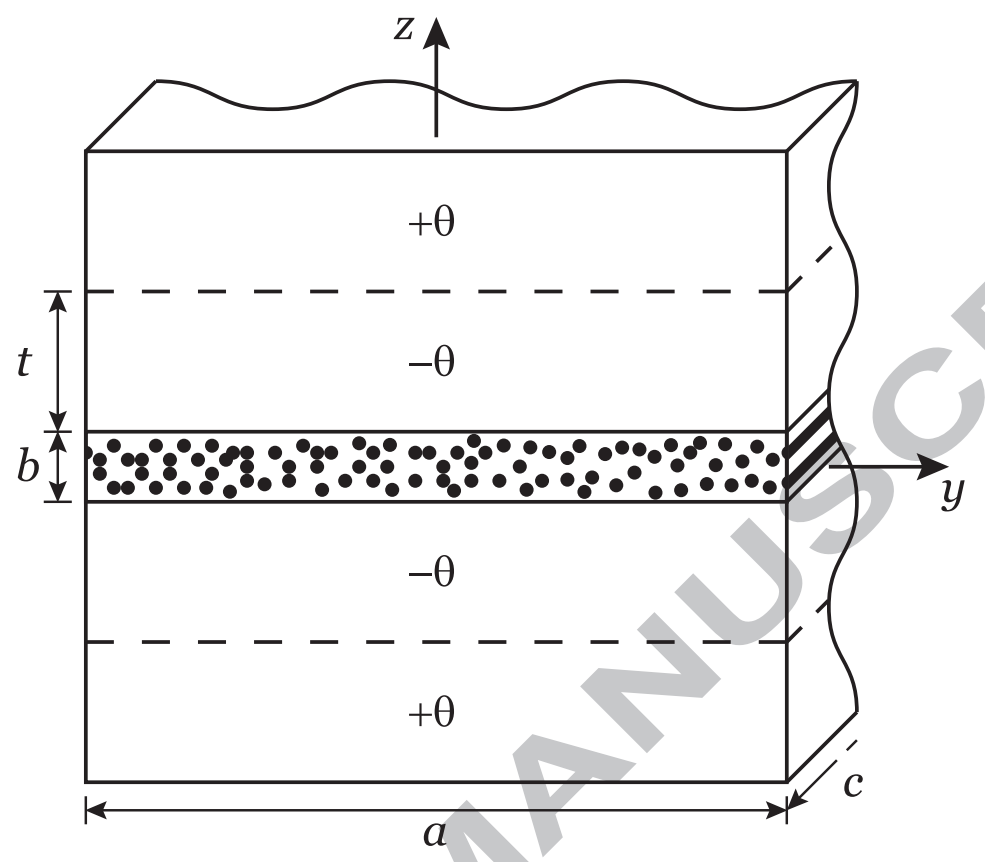

Figure 2: Schematic of the RVE of a thin-ply sublaminate. 


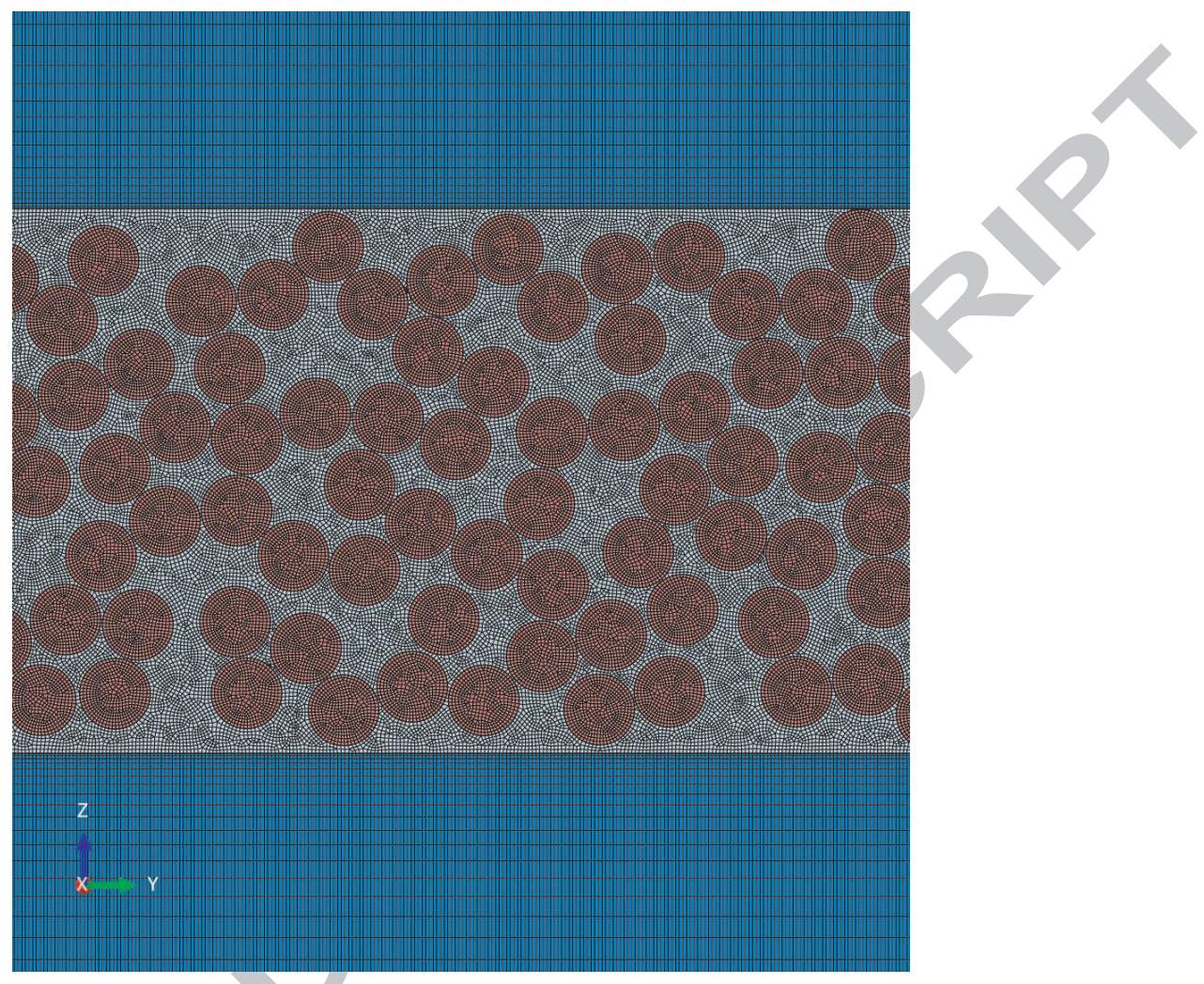

Figure 3: Representative FE model of part of an RVE with a $0.040 \mathrm{~mm}$ thick transverse ply. 


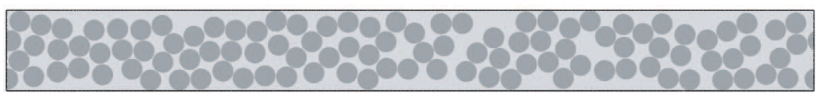

$+9.990 e-01$
$+0.000 e+00$

(a) Applied strain of $0.6 \%$.

$\mathrm{SDV}_{3}$

$+1.000 \mathrm{e}+00$

$+1.000 \mathrm{ee}-01$
$+9.990-01$
$+0.000 \mathrm{e}+00$

(b) Applied strain of $1.2 \%$.

\section{$\mathrm{SDV}_{3}$}

(Avg: 0\%)

$+1.000 e+00$
$++9.9000-01$

$+9.990 \mathrm{e}-01$
$+0.000 \mathrm{e}+00$

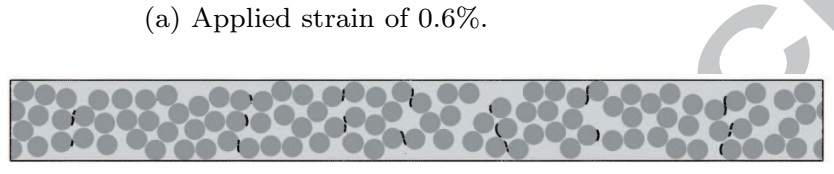

(b) Applied strain of $1.2 \%$.

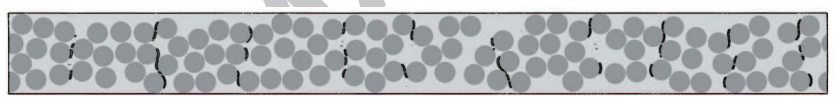

(c) Applied strain of $2.0 \%$.

Figure 4: Contour plots of the matrix damage variable on an RVE of a $0.020 \mathrm{~mm}$ thick $90^{\circ}$ lamina of a sublaminate with $0^{\circ}$ outer plies (only the $90^{\circ}$ lamina is shown). 


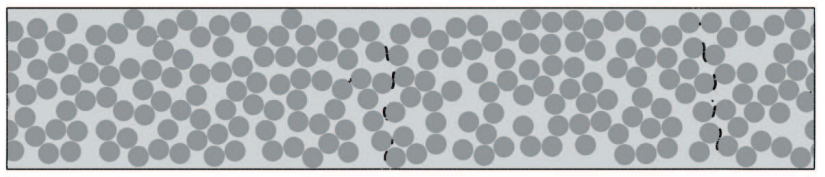

(a) Applied strain of $0.6 \%$.

SDV3
(Avg: 0\%)

$+1.000 \mathrm{e}+00$
$+9.9900-01$

$+9.990 \mathrm{e}-01$
$+0.000 \mathrm{e}+00$

(a) Applied strain of $0.6 \%$

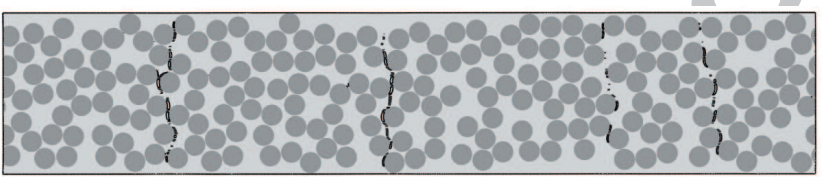

(b) Applied strain of $1.2 \%$.

$+1.000 \mathrm{e}+00$

$9.990 \mathrm{e}-01$
$0.000 \mathrm{e}+00$

(b) Applied strain of 1.2\%.

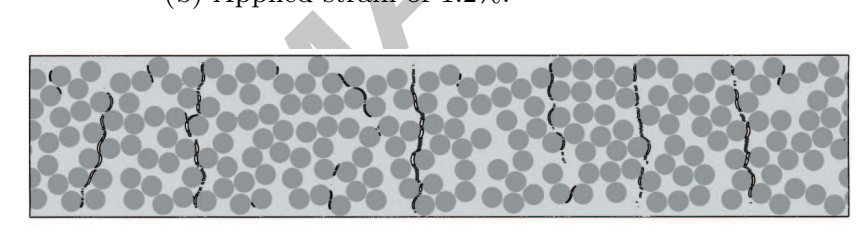

(c) Applied strain of $2.0 \%$.

Figure 5: Contour plots of the matrix damage variable on an RVE of a $0.040 \mathrm{~mm}$ thick $90^{\circ}$ lamina of a sublaminate with $0^{\circ}$ outer plies (only the $90^{\circ}$ lamina is shown). 
$\mathrm{SDV}_{3}$
(Avg: $0 \%)$

$+1.000 \mathrm{e}+00$

$+9.9900-01$
$+0.000 e+00$

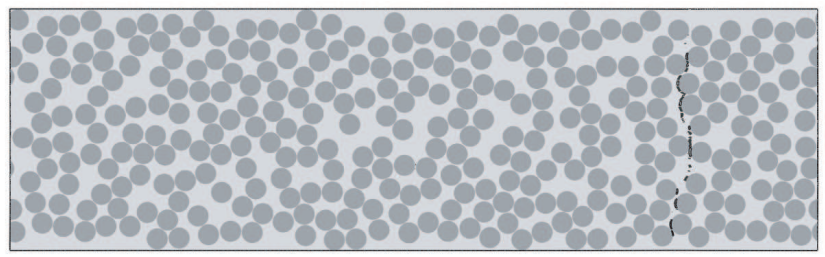

(a) Applied strain of $0.6 \%$.

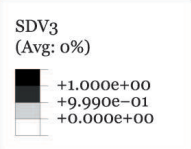

(b) Applied strain of $1.2 \%$.

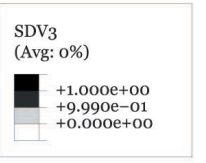

$+9.990 \mathrm{e}-01$
$+0.000 \mathrm{e}+00$

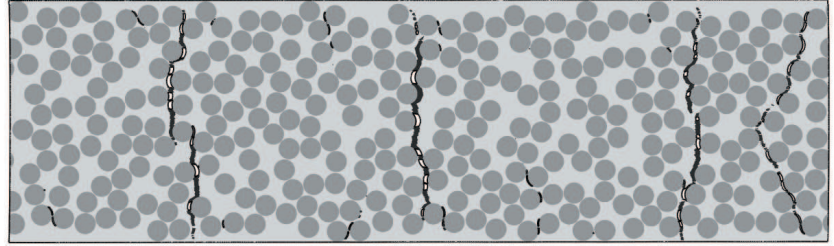

(c) Applied strain of $2.0 \%$.

Figure 6: Contour plots of the matrix damage variable on an RVE of a $0.060 \mathrm{~mm}$ thick $90^{\circ}$ lamina of a sublaminate with $0^{\circ}$ outer plies (only the $90^{\circ}$ lamina is shown). 
$\mathrm{SDV}_{3}$
(Avg: $0 \%)$

$+1.000 \mathrm{e}+00$

$+9.9900-01$
$+0.000 e+00$

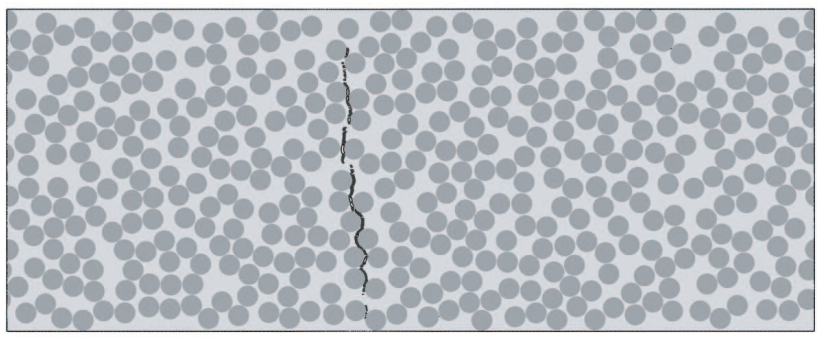

(a) Applied strain of $0.6 \%$.
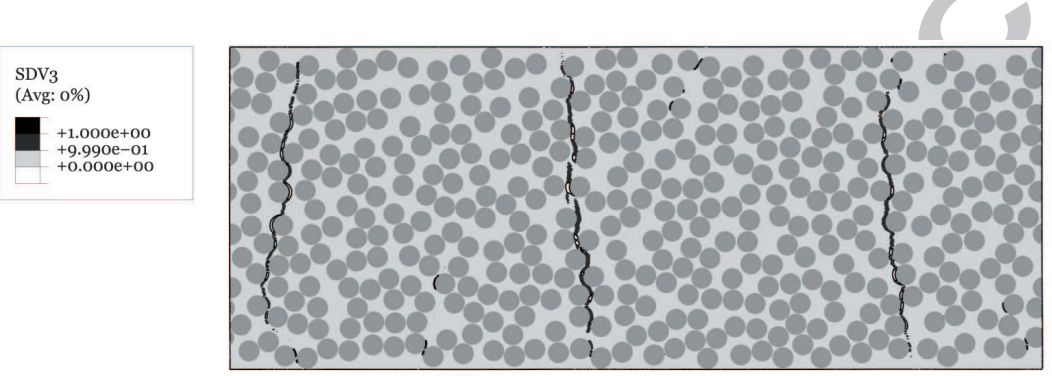

(b) Applied strain of $1.2 \%$.

\begin{tabular}{l} 
SDV3 \\
(Avg: $0 \%)$ \\
$\square \begin{array}{r}+1.000 e+00 \\
+9.990 e-01 \\
+0.000 e+00\end{array}$ \\
\hline
\end{tabular}

Figure 7: Contour plots of the matrix damage variable on an RVE of a $0.080 \mathrm{~mm}$ thick $90^{\circ}$ lamina of a sublaminate with $0^{\circ}$ outer plies (only the $90^{\circ}$ lamina is shown). 

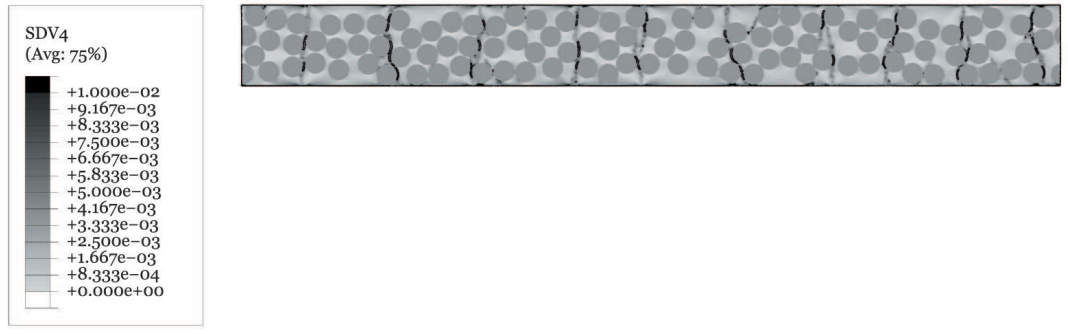

(a) $0.020 \mathrm{~mm}$ thick transverse ply.
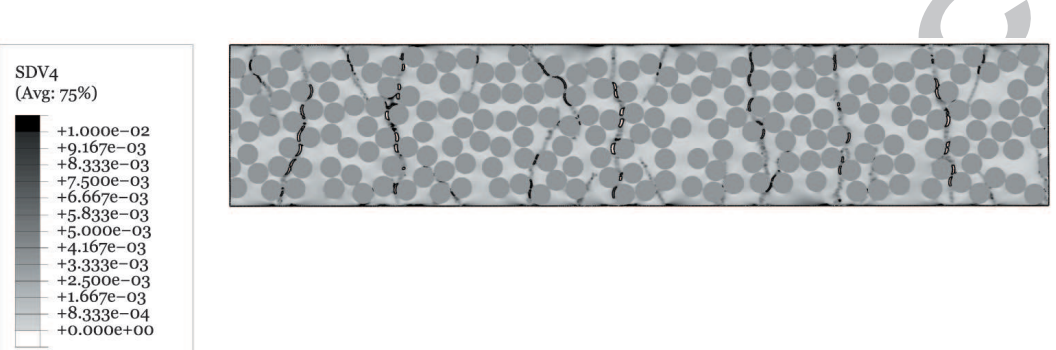

(b) $0.040 \mathrm{~mm}$ thick transverse ply.
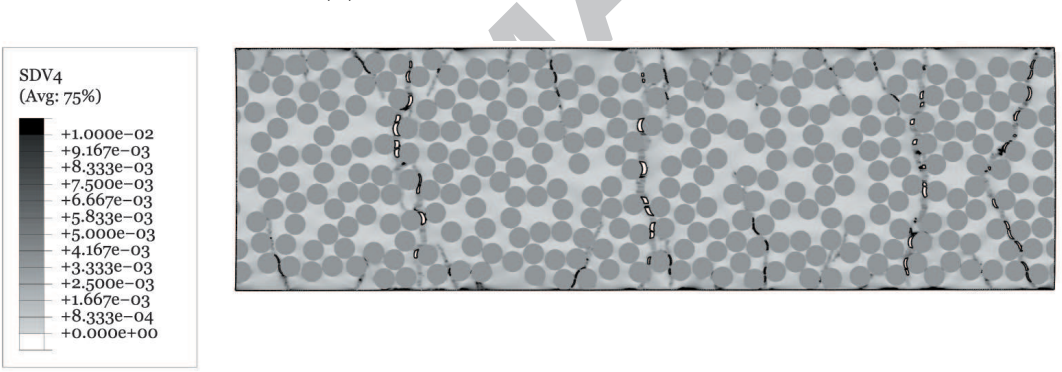

(c) $0.060 \mathrm{~mm}$ thick transverse ply.

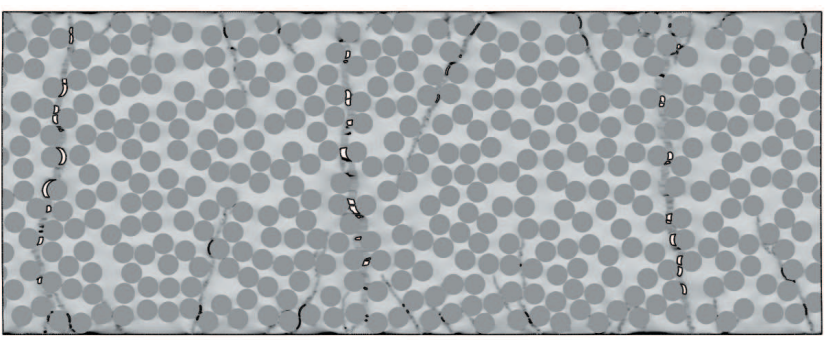

(d) $0.080 \mathrm{~mm}$ thick transverse ply.

Figure 8: Contour plots of the equivalent plastic strain in the matrix of RVEs of $90^{\circ}$ laminae on thin-ply sublaminates with $0^{\circ}$ outer plies, at an applied strain of $2.0 \%$ (only the $90^{\circ}$ laminae are shown). 

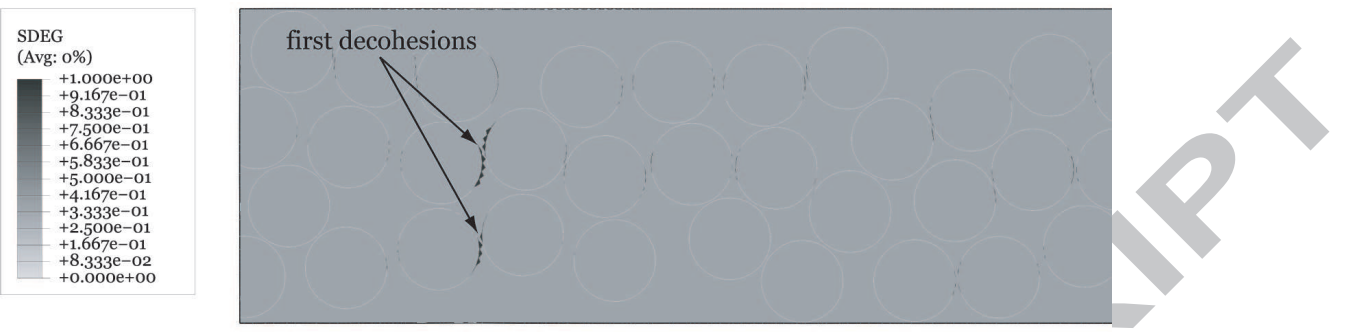

Figure 9: Damage variable of the cohesive elements representing the interface between fibre and matrix in a detail of the $0.020 \mathrm{~mm}$ thick ply RVE at an applied strain of $0.6 \%$. 

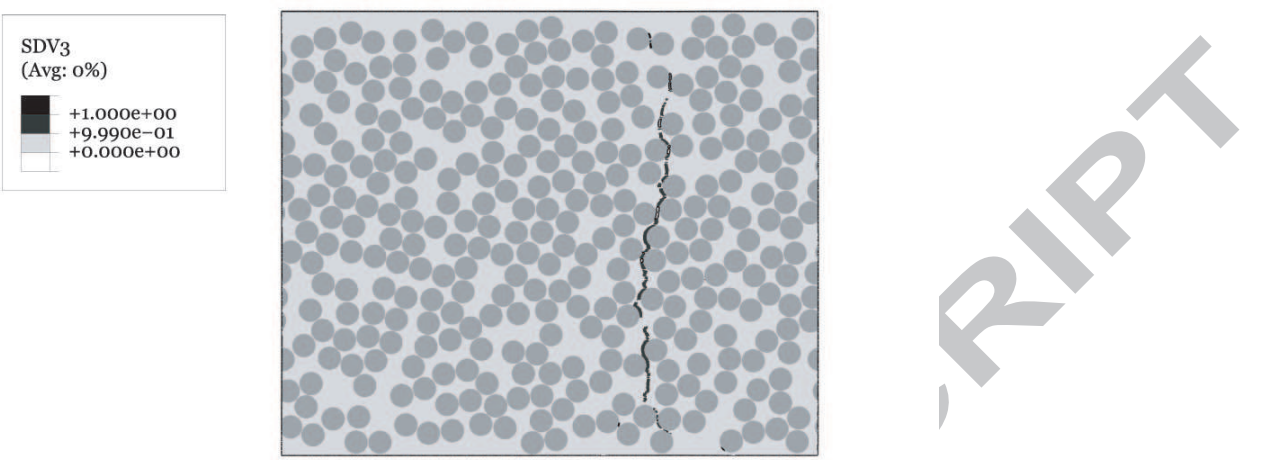

(a) Applied strain of $0.6 \%$.

\begin{tabular}{|l|}
\hline $\begin{array}{l}\text { SDV3 } \\
\text { (Avg: 0\%) }\end{array}$ \\
$\begin{array}{r}+1.000 e+00 \\
+9.990 e-01 \\
+0.000 e+00\end{array}$ \\
\hline
\end{tabular}

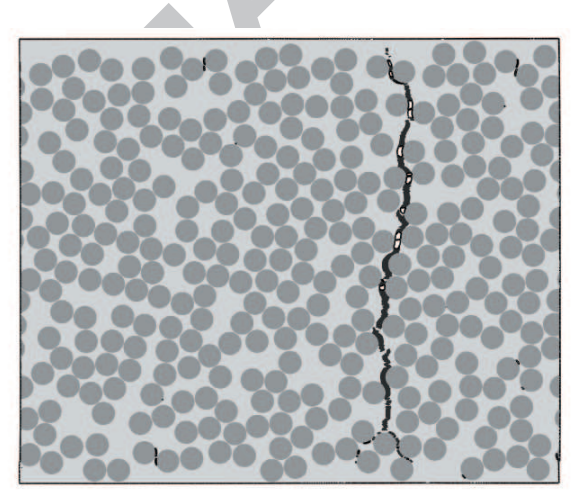

(b) Applied strain of $1.2 \%$.

Figure 10: Contour plots of the matrix damage variable on an RVE of a $0.100 \mathrm{~mm}$ thick $90^{\circ}$ lamina of a sublaminate with $0^{\circ}$ outer plies (only the $90^{\circ}$ lamina is shown). 


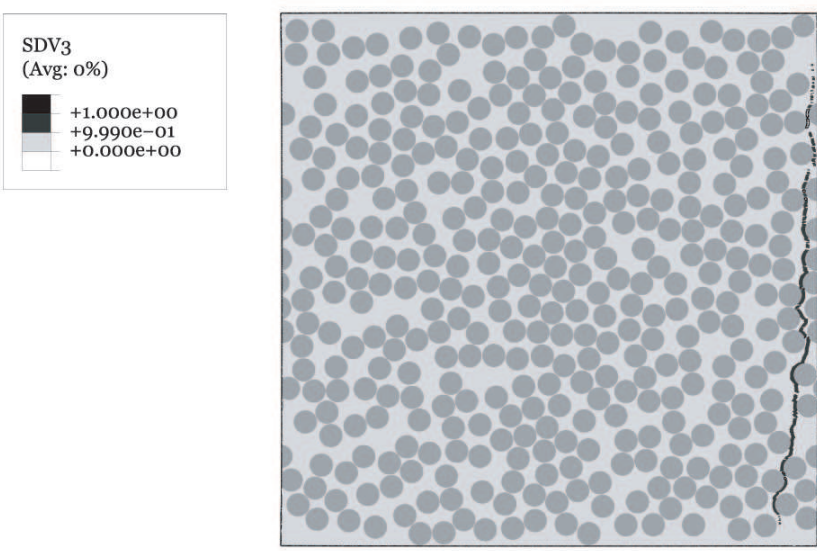

(a) Applied strain of $0.6 \%$.

\begin{tabular}{|l|}
\hline SDV3 \\
(Avg: $0 \%)$ \\
$\square$ \\
$+1.000 e+00$ \\
$+9.990 e-01$ \\
$+0.000 e+00$
\end{tabular}

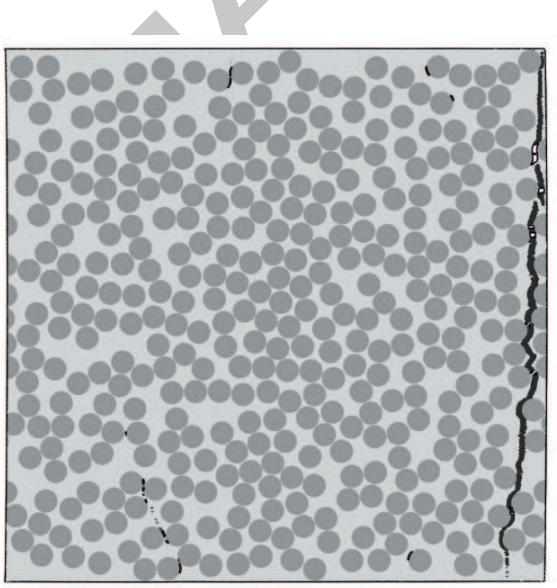

(b) Applied strain of $1.2 \%$.

Figure 11: Contour plots of the matrix damage variable on an RVE of a $0.120 \mathrm{~mm}$ thick $90^{\circ}$ lamina of a sublaminate with $0^{\circ}$ outer plies (only the $90^{\circ}$ lamina is shown). 

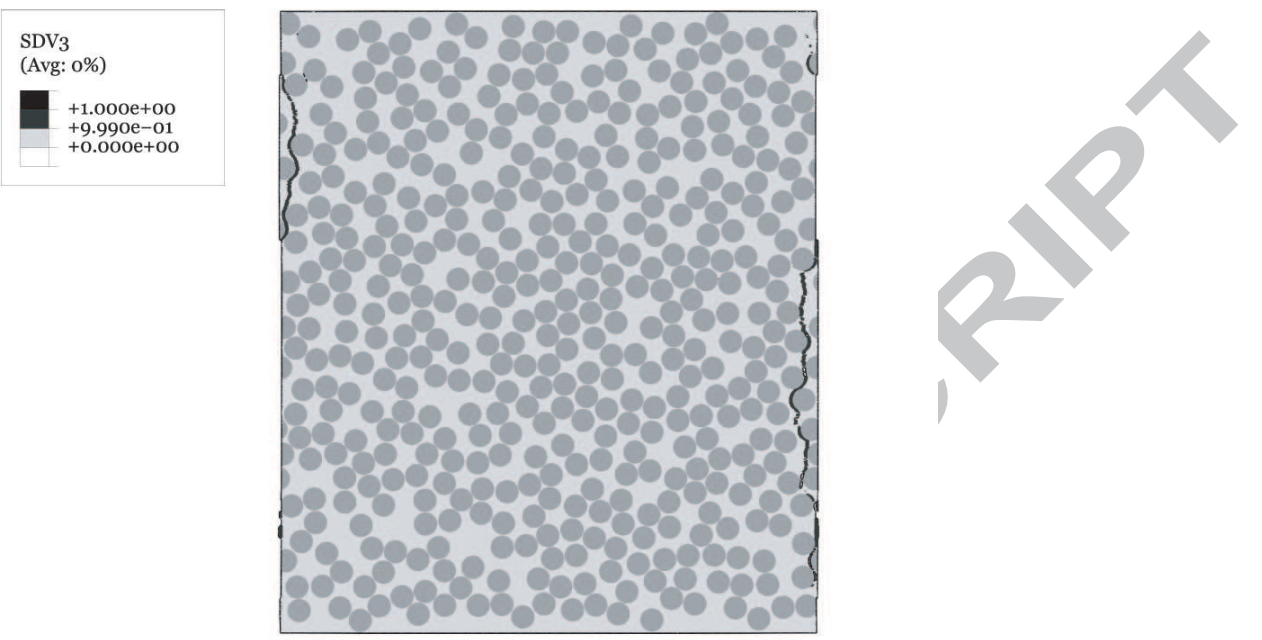

(a) Applied strain of $0.6 \%$.

\begin{tabular}{|l|}
\hline $\begin{array}{l}\text { SDV } 3 \\
\text { (Avg: 0\%) }\end{array}$ \\
$\begin{array}{r}+1.000 e+00 \\
+9.990 e-01 \\
+0.000 e+00\end{array}$ \\
\hline
\end{tabular}

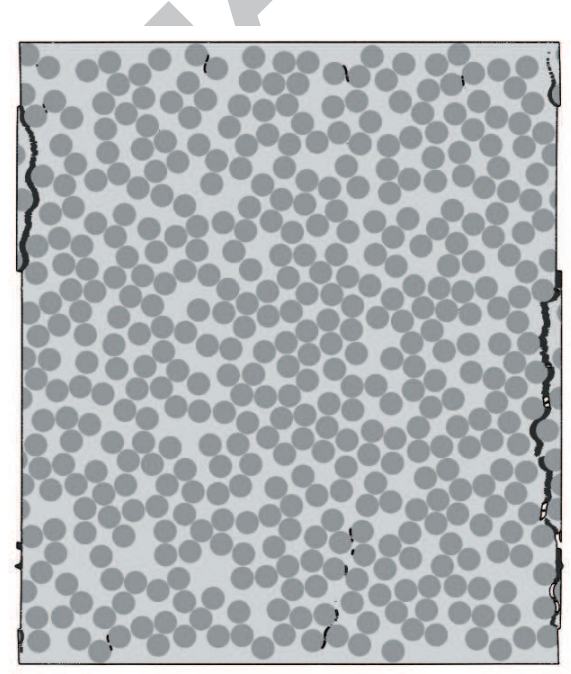

(b) Applied strain of $1.2 \%$.

Figure 12: Contour plots of the matrix damage variable on an RVE of a $0.140 \mathrm{~mm}$ thick $90^{\circ}$ lamina of a sublaminate with $0^{\circ}$ outer plies (only the $90^{\circ}$ lamina is shown). 


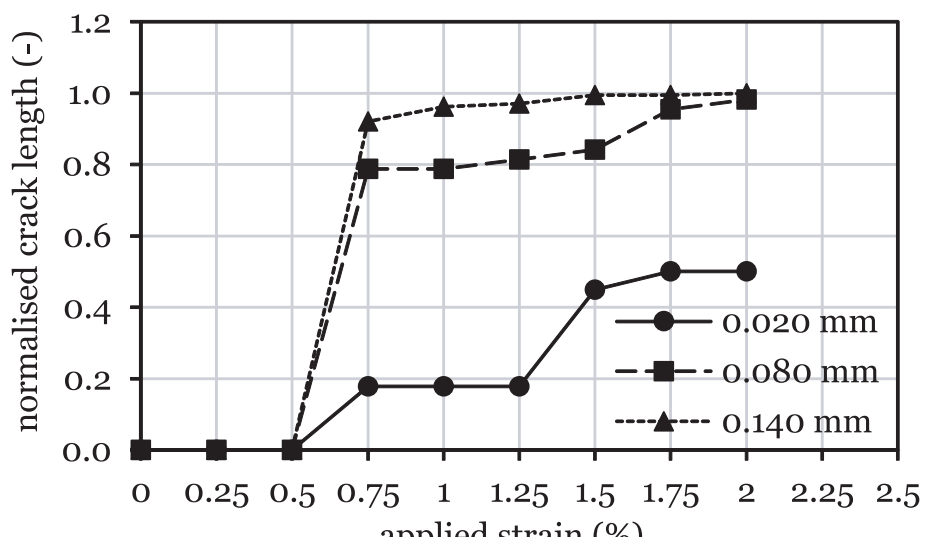

applied strain (\%)

Figure 13: Normalised crack length as a function of applied strain for sublaminate RVEs with $0.020 \mathrm{~mm}, 0.080 \mathrm{~mm}$ and $0.140 \mathrm{~mm}$ thick transverse plies. 

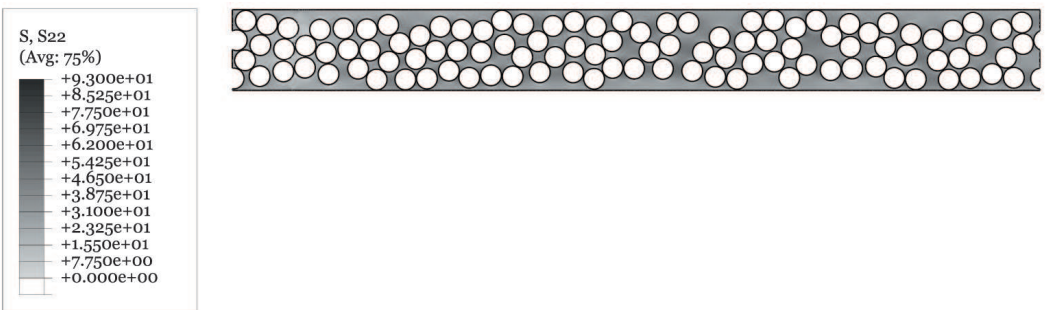

(a) Applied strain of $0.6 \%$.

S, S22
(Avg: $75 \%)$

$+9.300 e+01$
$+8.525 e+01$

$+8.525 \mathrm{e}+01$
$+7.750 \mathrm{e}+01$

$+6.975 \mathrm{e}+\mathrm{+}$

$+6.200 \mathrm{e}+0$
$+5.425 \mathrm{e}+\mathrm{0}$
+

$+5.425 \mathrm{e}+01$
$+4.650 \mathrm{e}+\mathrm{O}$
$+3.875 \mathrm{e}+01$

$+3.875 e+01$
$+3.100++01$

$+2.325 \mathrm{e}+0$

$+1.550 \mathrm{e}+0$

$+7.750 \mathrm{e}+00$
$+0.000 \mathrm{e}+00$

(b) Applied strain of $2.0 \%$.

Figure 14: Transverse stress field $\left(\sigma_{22}\right)$ in a cracked $0.020 \mathrm{~mm}$ thick $90^{\circ}$ ply of a sublaminate with $0^{\circ}$ outer plies (only the matrix material of the $90^{\circ}$ ply is shown). 

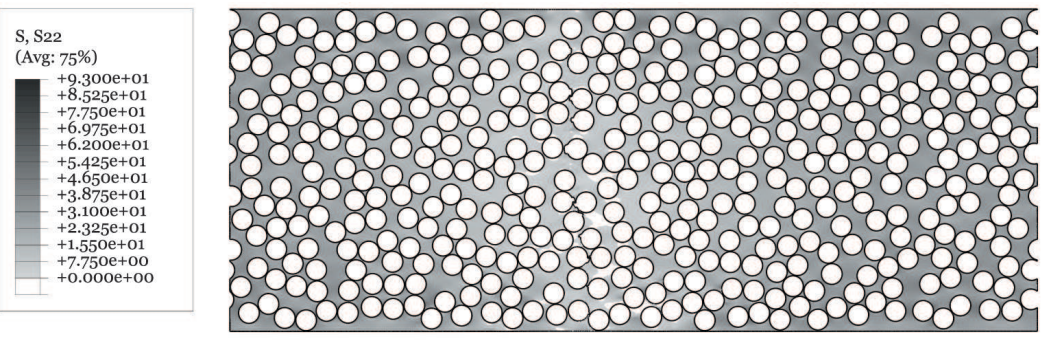

(a) Applied strain of $0.6 \%$.
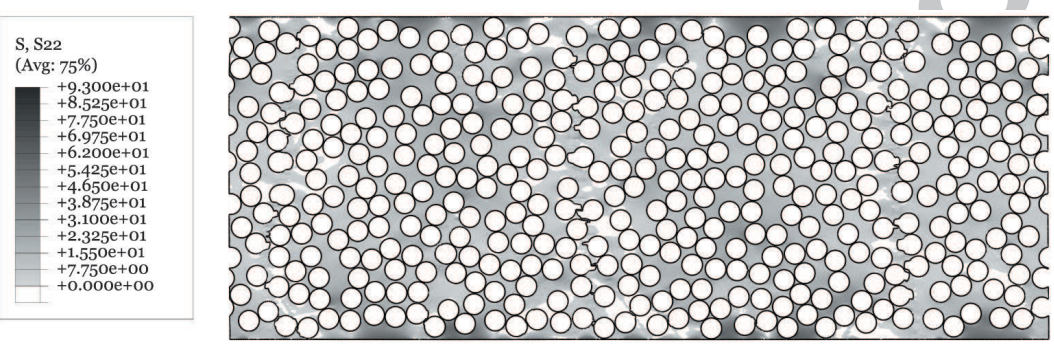

(b) Applied strain of $2.0 \%$.

Figure 15: Transverse stress field $\left(\sigma_{22}\right)$ in a cracked $0.080 \mathrm{~mm}$ thick $90^{\circ}$ ply of a sublaminate with $0^{\circ}$ outer plies (only the matrix material of the $90^{\circ}$ ply is shown). 


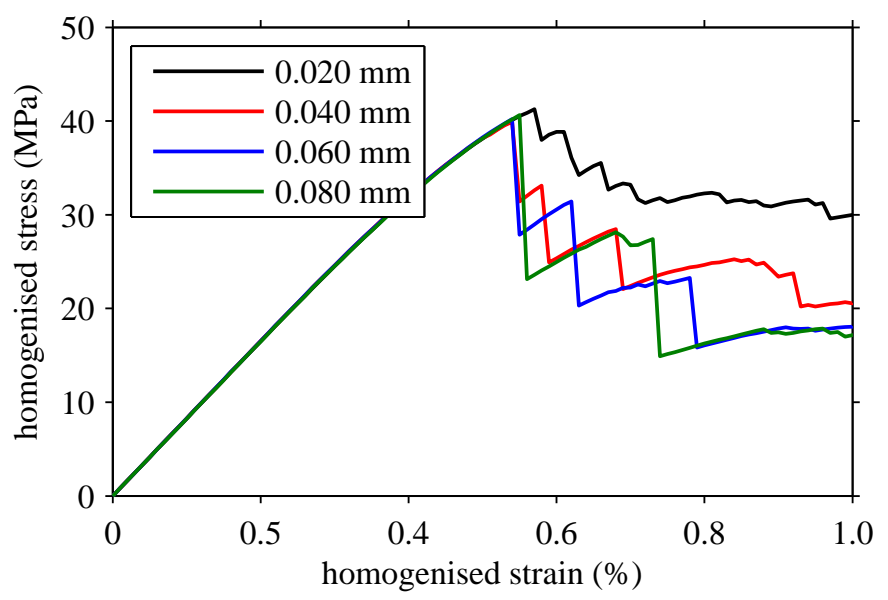

Figure 16: Homogenised stress-strain curves of the embedded $90^{\circ}$ ply for sublaminates with $0^{\circ}$ outer plies. (For interpretation of the references to colour in this figure legend, the reader is referred to the web version of this article.) 


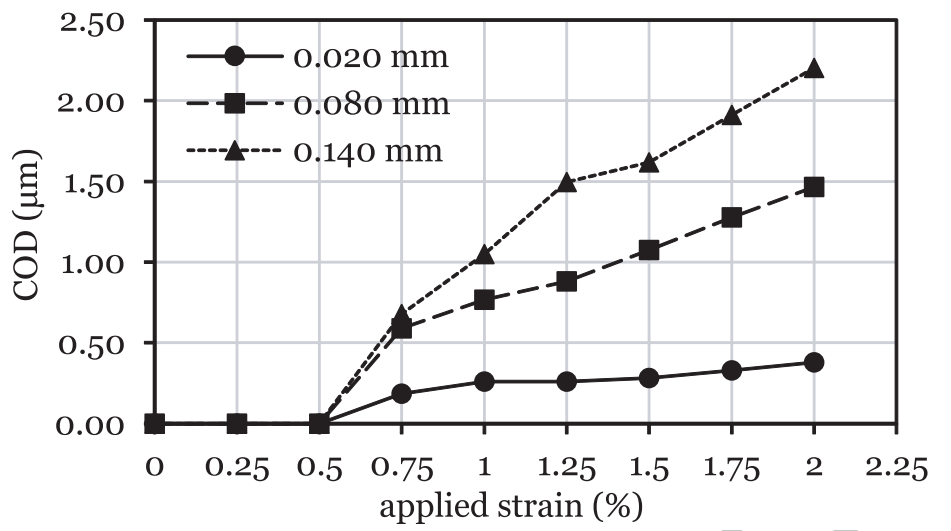

Figure 17: COD as a function of applied strain for sublaminate RVEs with $0.020 \mathrm{~mm}$, $0.080 \mathrm{~mm}$ and $0.140 \mathrm{~mm}$ thick transverse plies. 

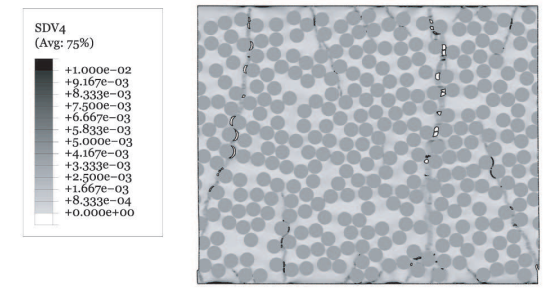

(a) $0.100 \mathrm{~mm}$ thick transverse ply.
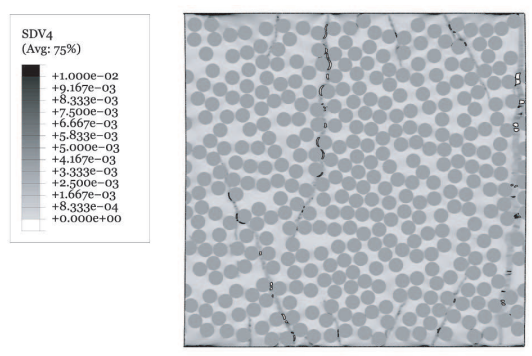

(b) $0.120 \mathrm{~mm}$ thick transverse ply.

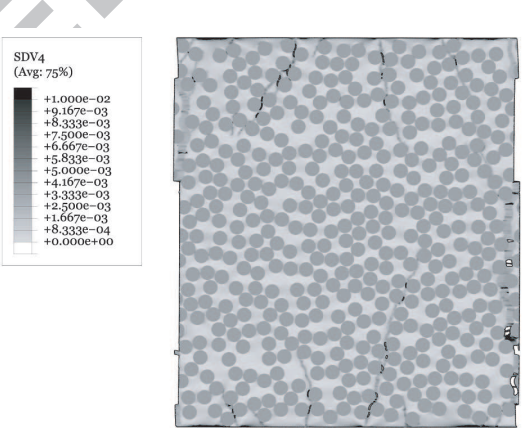

(c) $0.140 \mathrm{~mm}$ thick transverse ply.

Figure 18: Contour plots of the equivalent plastic strain in the matrix of RVEs of $90^{\circ}$ laminae on sublaminates with $0^{\circ}$ outer plies, at an applied strain of $2.0 \%$ (only the $90^{\circ}$ laminae are shown). 


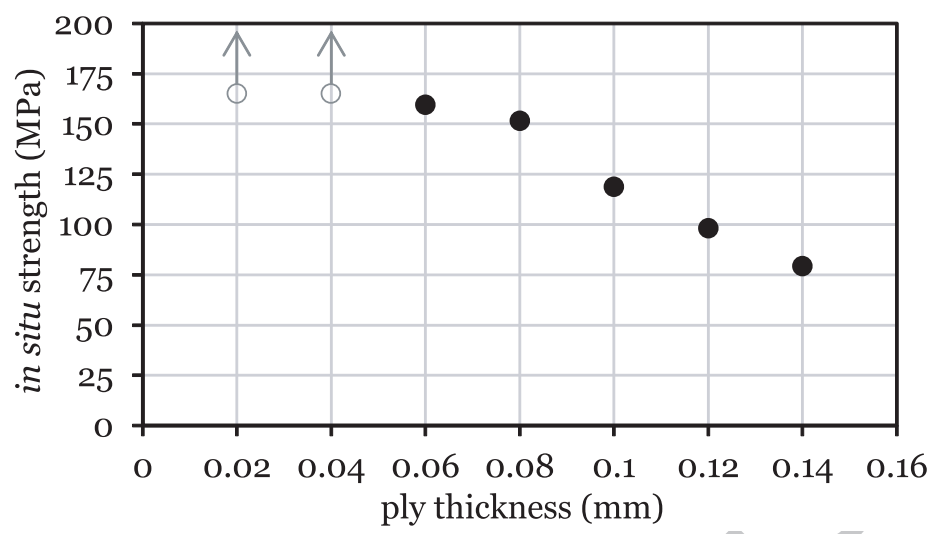

Figure 19: In situ transverse strength as a function of the ply thickness. 


\section{List of Tables}

1 Carbon fibre material properties. . . . . . . . . . . . . 50

2 Epoxy matrix material properties. . . . . . . . . . . . 51

3 Fibre-matrix interface properties. . . . . . . . . . . . . . 52

4 Homogenised outer plies (IM7/8552) material properties. . . . . . 53

5 Interlaminar interface properties of the IM7/8552 carbon-epoxy composite laminate. . . . . . . . . . . . . . . . . 54

$6 \quad$ Size of the sublaminate RVEs studied in the present work. . . . 55 
Table 1: Carbon fibre material properties.

\begin{tabular}{ll}
\hline Material property & Value \\
\hline Fibre diameter & \\
$2 R(\mathrm{~mm})$ & 0.0052 \\
Fibre volume fraction & \\
$V_{f}(\%)$ & 59.1 \\
Young's moduli & \\
$E_{11}(\mathrm{MPa})$ & 276000 \\
$E_{22}(\mathrm{MPa})$ & 15000 \\
Poisson's ratio & 0.2 \\
$\nu_{12}$ & \\
Shear moduli & 15000 \\
$G_{12}(\mathrm{MPa})$ & 7000 \\
$G_{23}(\mathrm{MPa})$ & \\
Coefficients of thermal expansion & $-0.5 \times 10^{-6}$ \\
$\alpha_{11}\left({ }^{\circ} \mathrm{C}^{-1}\right)$ & $15 \times 10^{-6}$ \\
$\alpha_{22}\left({ }^{\circ} \mathrm{C}^{-1}\right)$ & \\
Critical energy release rate & \\
$\mathcal{G}_{c}(\mathrm{~N} / \mathrm{mm})$ & 90 \\
Tensile strength & \\
$X_{T}(\mathrm{MPa})$ & 5310 \\
Compressive strength & \\
$X_{C}(\mathrm{MPa})$ & 3500 \\
Density & \\
$\left(\mathrm{kg} / \mathrm{mm}{ }^{3}\right)$ & $1.78 \times 10^{-9}$ \\
\hline
\end{tabular}


Table 2: Epoxy matrix material properties.

\begin{tabular}{lc}
\hline Material property & Value \\
\hline Young's modulus & 3760 \\
$E(\mathrm{MPa})$ & \\
Poisson's ratio & 0.39 \\
$\nu$ & \\
Coefficient of thermal expansion & $58 \times 10^{-6}$ \\
$\alpha\left({ }^{\circ} \mathrm{C}^{-1}\right)$ & \\
Stress free temperature & 155 \\
$T_{0}\left({ }^{\circ} \mathrm{C}\right)$ & \\
Plastic Poisson's ratio & 0.3 \\
$\nu_{p}$ & \\
Critical energy release rate & 0.277 \\
$\mathcal{G}_{c}(\mathrm{~N} / \mathrm{mm})$ & \\
Tensile strength & 93 \\
$X_{T}(\mathrm{MPa})$ & \\
Compressive strength & 350 \\
$X_{C}(\mathrm{MPa})$ & \\
Density & \\
$\left(\mathrm{kg} / \mathrm{mm}{ }^{3}\right)$ & \\
\hline
\end{tabular}


Table 3: Fibre-matrix interface properties.

\begin{tabular}{lc}
\hline Material property & Value \\
\hline Interface stiffness & $10^{8}$ \\
$K\left(\mathrm{~N} / \mathrm{mm}^{3}\right)$ & \\
Interface maximum strengths & 50 \\
$\tau_{1}^{0}(\mathrm{MPa})$ & 75 \\
$\tau_{2}^{0}(\mathrm{MPa})$ & 75 \\
$\tau_{3}^{0}(\mathrm{MPa})$ & \\
Interface critical energy release rates & 0.002 \\
$\mathcal{G}_{\text {Ic }}(\mathrm{N} / \mathrm{mm})$ & 0.006 \\
$\mathcal{G}_{\text {IIc }}(\mathrm{N} / \mathrm{mm})$ & 0.006 \\
$\mathcal{G}_{I I I c}(\mathrm{~N} / \mathrm{mm})$ & \\
Mixed-mode interaction parameter $(\mathrm{BK}$ law $[62])$ & 1.45 \\
$\eta$ & \\
\hline
\end{tabular}


Table 4: Homogenised outer plies (IM7/8552) material properties.

\begin{tabular}{ll}
\hline Material property & Value \\
\hline Young's moduli & \\
$E_{11}(\mathrm{MPa})$ & 171420 \\
$E_{22}(\mathrm{MPa})$ & 9080 \\
Poisson's ratio & \\
$\nu_{12}$ & 0.32 \\
Shear moduli & 5290 \\
$G_{12}(\mathrm{MPa})$ & 3920 \\
$G_{23}(\mathrm{MPa})$ & $-5.5 \times 10^{-6}$ \\
Coefficients of thermal expansion & $25.8 \times 10^{-6}$ \\
$\alpha_{11}\left({ }^{\circ} \mathrm{C}^{-1}\right)$ & \\
$\alpha_{22}\left({ }^{\circ} \mathrm{C}^{-1}\right)$ & $1.57 \times 10^{-9}$ \\
Density & \\
$\left(\mathrm{kg} / \mathrm{mm}^{3}\right)$ & \\
\hline
\end{tabular}


Table 5: Interlaminar interface properties of the IM7/8552 carbon-epoxy composite laminate.

\begin{tabular}{lc}
\hline Material property & Value \\
\hline Interface stiffness & \\
$K\left(\mathrm{~N} / \mathrm{mm}^{3}\right)$ & $10^{8}$ \\
Interface maximum strengths & \\
$\tau_{1}^{0}(\mathrm{MPa})$ & 93 \\
$\tau_{2}^{0}(\mathrm{MPa})$ & 71 \\
$\tau_{3}^{0}(\mathrm{MPa})$ & 71 \\
Interface critical energy release rates & 0.277 \\
$\mathcal{G}_{I c}(\mathrm{~N} / \mathrm{mm})$ & 0.788 \\
$\mathcal{G}_{I I c}(\mathrm{~N} / \mathrm{mm})$ & 0.788 \\
$\mathcal{G}_{I I I c}(\mathrm{~N} / \mathrm{mm})$ & \\
$M_{\text {ixed-mode interaction parameter }(\mathrm{BK} \text { law }[62])}$ & 1.634 \\
$\eta$
\end{tabular}


Table 6: Size of the sublaminate RVEs studied in the present work.

\begin{tabular}{ll}
\hline Ply thickness $(b)$ & RVE's width, $y y$-direction $(a)$ \\
\hline $0.020 \mathrm{~mm}$ & $0.200 \mathrm{~mm}$ \\
$0.040 \mathrm{~mm}$ & $0.200 \mathrm{~mm}$ \\
$0.060 \mathrm{~mm}$ & $0.200 \mathrm{~mm}$ \\
$0.080 \mathrm{~mm}$ & $0.200 \mathrm{~mm}$ \\
$0.100 \mathrm{~mm}$ & $0.120 \mathrm{~mm}$ \\
$0.120 \mathrm{~mm}$ & $0.120 \mathrm{~mm}$ \\
$0.140 \mathrm{~mm}$ & $0.120 \mathrm{~mm}$ \\
\hline
\end{tabular}

